\title{
Yapay sinir ağları ile görüntü işlemeye dayalı uzaklıktan bağımsız ağırlık tahmin sistemi: yumurta ve portakal örnekleri
}

\author{
Ünsal Burak Şalvarcı' (iD), Umut Engin Ayten ${ }^{1 *}$ (i) \\ ${ }^{1}$ Yıldız Teknik Üniversitesi, Davutpaşa Kampüsü, Elektrik-Elektronik Fakültesi, Elektronik ve Haberleşme Mühendisliği Bölümü, Esenler, Istanbul.
}

\begin{abstract}
Öz: Endüstriyel ve akademik çalışmalarda objelerin ağırlıklarının ölçülmesi oldukça önemli bir yere sahiptir. Bu nedenle gerçekleştirilmiş olan bu çalışmada yapay sinir ağları (YSA) kullanılarak görüntü işlemeye dayalı uzaklıktan ve kamera açısından bağımsız ağırlık tahmini yapılması amaçlanmıştır. Yapay sinir ağ yapısı olarak ileri beslemeli çok katmanlı algılayıcı (multi-layer perceptron - MLP) ve radyal

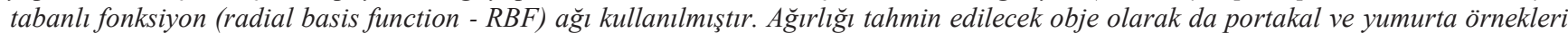
belirlenmiştir. Bu örnekler ile sistemin eğitilmesi ve test edilmesi için; 4 farklı marka ve 4 farklı sınıf (çok büyük - büyük - orta - küçük) olacak şekilde 250 adet yumurta örneği ve farklı boyutlarda 150 adet portakal örneği seçilmiştir. Bu örnekler kullanılarak; yumurta için dik açı, pozitif açı ve negatif açı ile elde edilmiş 750 adet görüntü içeren, portakal için de dik açı, pozitif açı ve negatif açı ile elde edilmiş 450 adet görüntü içeren bir veri tabanı oluşturulmuştur. Oluşturulan bu ağırlık tahmin sistemi; bir adet kamera, yapay aydınlatma sistemi, yansitıcılar ve referans görüntüden oluşmaktadır ve ayrıca ağırlık tahmin işlemi sırasında MATLAB programı ve araç kutuları kullanılmıştır. Bu çalışmada farklı öznitelik vektörleri, farklı açılardan çekilmiş görüntüler ve farklı YSA parametreleri test edilerek başarımı en yüksek olan sistemin kurulması hedeflenmiştir. Her bir değişiklik sonucu oluşturulan sistem beşer kez çalıştırılarak sonuçların aritmetik ortalaması alınmıştır. Ayrıca başarımı en yüksek olan denemenin, k-katlı çapraz doğrulama yöntemi ile de başarımı hesaplanmıştır. Hassas tartı ile yapılan ölçümlerde, Türk Gıda Kodeksi Yumurta Tebliği’ne göre belirlenmiş ve yumurta kutularının üzerinde yazan sinıflandırma değerlerine göre doğruluk oranı \%47 iken, gerçekleştirilen bu çallşma sonucunda bu oran MLP'de \% 90.50'e, RBF'de \% 86.30'e çıkarılmıştır. Ayrıca ağırlık tahmininin başarımı; MLP için yumurta örneğinde \% 99.42, portakal örneğinde \% 98.20 ve RBF için yumurta örneğinde \% 99.43, portakal örneğinde \%98.25 olarak hesaplanmıştır.
\end{abstract}

Anahtar Sözcükler: Ağırlık tahmini, Sayısal görüntü işleme, Yapay sinir ağı, Çok katmanlı algılayıcı, Radyal tabanlı fonksiyon

\section{Distance independent weight estimation system based on image processing with artificial neural networks: egg and orange samples}

\begin{abstract}
Measuring the weights of the objects in industrial and academic studies is highly important. Therefore, it is aimed to perform weight estimation as independent of distance and camera angle using artificial neural networks (ANN) based on image processing procedure in this study. Feed-forward multi-layer perceptron $(M L P)$ and radial basis function $(R B F)$ network were used as artificial neural network structure. Orange and egg were selected as sample objects to be estimated the weights. To train and test the system with these samples, 250 eggs samples from 4 different brands and classes ( $x$-large, large, medium, and small) and 150 oranges samples with different sizes were selected. Using these samples, a database containing 750 images for eggs and 450 images for oranges taken under the right angle, positive angle and negative angle was created. The weight estimation system consists of a camera, artificial lighting system, reflector and reference image and also the MATLAB program and toolboxes were used during the weight estimation process. In this study, to establish a system with highest success value was aimed by testing the different feature vectors, images taken from different angles and different ANN parameters. The system created by each change was run five times and arithmetic mean of the results was taken. In addition, the experience, which has the highest success value, was also calculated by $K$-fold cross validation method to obtain the success value. While the accuracy rate obtained from the results weighted by accurate weighting instrument is $47 \%$ according to definition of Turkish food codex egg communique and classification values written on the egg cartoon, this rate was increased to $90.5 \%$ for MLP, 86.35 for RBF in this study. Moreover, the success rates of the weight estimation for MLP and RBF were calculated as $99.42 \%$ for eggs, $98.20 \%$ for oranges and $99.43 \%$ for eggs, $98.25 \%$ for oranges, respectively.
\end{abstract}

Keywords: Weight estimation, Digital image processing, Artificial neural network, Multi-layer perceptron, Radial basis function

\footnotetext{
* Sorumlu Yazar/Corresponding Author: Tel: +90 2123835885 


\section{Giriş}

Ağırlık ölçümü binlerce yıl öncesinden günümüze gelen ve birçok alanda yaygın olarak kullanılan bir işlemdir. İlk zamanlarda bir dayanak noktasına göre eşit uzaklıklarda ağırlığı bilinen bir kütle ile bilinmeyen bir kütlenin konularak dengeye getirilmesi yöntemiyle ağırlıklar hesaplanmıştır. Zamanla hassasiyetin ve ihtiyaçların artmasıyla; günümüzde, bir platforma yerleştirilen ağırlık sonucunda oluşan baskıyı elektrik sinyaline dönüştüren hassas dijital teraziler gibi farklı çözümler üretilmiştir (URL-1). Günümüzde ise özellikle endüstriyel alanlarda gerçekleştirilen çalışmalarda objelerin ağırlıklarının hızlı ve doğru olarak ölçülmesi oldukça önem taşımaktadır. Bu nedenle farklı yöntemler ile hızlı ve başarımı yüksek ağırlık ölçümü üzerine akademik çalışmalar yaygın olarak gerçekleştirilmiştir.

Literatürde, Asadi ve Raoufat (2010) çalışmasında sayısal görüntü işleme ile yumurtaların ağırlıklarını tahmin etmiştir. Bu çalışmada yük bağlaşımlı aygıt (Charge Coupled Device- CCD) kamera kullanılmıştır. Ayrıca, aydınlatma sistemi ile olası görüntü problemlerinin önüne geçilmiş ve bir adet ayna yardımı ile de objenin farklı açıdan görüntüsü elde edilmiştir. Çok katmanlı algılayıcı (multi-layer erceptron - MLP) kullanılarak gerçekleştirilen bu çalışmada korelasyon katsayısı \%96 olarak hesaplanmıştır. Javadikia, Dehrouyeh, Naderloo, Rabbani ve Lorestani (2011) tarafından, ağ tabanlı bulanık çıkarım sistemi (adaptive-network based fuzzy inference systems - ANFIS) kullanılarak yapılan başka bir yumurta ağırlığı tahmin çalışmasında 200 görüntü kullanılmıştır. Benzer şekilde CCD kamera ve aydınlatma sistemi ile oluşturulan ölçüm düzeneği ile objelerin ağırlıkları tahmin edilmeye çalışılmış ve korelasyon katsayısı \%99.42 olarak hesaplanmıştır. Alikhanov vd. (2015) tarafından yapılan bir çalışmada ise yine CCD kamera ve aydınlatma sistemi ile kurulan ölçüm düzeneğinde yumurta ağırlığının tahmin edilmesi üzerine gerçekleştirilen çalışmada regresyon analizi kullanılmıştır. MATLAB programı ile gerçekleştirilen bu çalışmada korelasyon katsayısı \%94.39 bulunmuştur. Literatür taraması sonucunda, ağırlık tahmini ile ilgili yapılan çalışmalarda yumurta dışında somon balıkları, domuzlar, turunçgiller vb. farklı objeler ile uygulamalar gerçekleştirildiği görülmektedir. Hockaday, Ross ve Tillett (1997) ve Lines vd. (2001) tarafından gerçekleştirilen çalışmada 17 balıktan 1-2 metre uzaklıktaki 2 kamera yardımıyla 60 görüntü elde edilmiştir. Bu çalışma sonucunda ortalama kütle ölçüm hatası \%18 olarak hesaplanmıştır. Omid, Khojastehnazhand ve Tabatabaeefar (2010) tarafindan turunçgiller üzerinde gerçekleştirilen başka bir çalışmada ise portakal, limon, misket limonu ve mandalina kullanılmıştır. Her bir örnek obje için 50 adet görüntü elde edilmiştir. Bu çalışma sonucunda korelasyon katsayısının karesi olan belirleme katsayısı; limonda \%96.2, misket limonunda \%97, portakalda \%98.5 ve mandalinada ise \%96 olarak hesaplanmıştır. Kashiha vd. (2014) çalışmasında ise domuzların ağırlıklarını tahmin etmek için 2 farklı deney gerçekleştirmiştir. Her bir deney için elde edilen 156 saatlik görüntü anlık olarak incelenerek transfer fonksiyonu metodu ile domuzların ağırlıkları tahmin edilmiştir. Bu çalışmada \%97.5'lik bir başarım elde edilmiştir.

Gerçekleştirilen bu çalışmada da yapay sinir ağları (YSA) kullanılarak sayısal görüntü işleme tekniğiyle uzaklıktan bağımsız olarak ağırlık tahmini yapılmıştır. Tahmin işlemi gıda sektöründe farklı kategorilerde olan yumurta ve portakal örnekleri üzerinde gerçekleştirilmiştir. Yumurta, içerdiği besin maddeleri ile insan vücudunun ihtiyaçlarını büyük oranda karşılayabilmektedir. Yapısında bulunan biyolojik değeri yüksek protein sayesinde insan hayatında oldukça önemli bir yere sahiptir. Ayrıca yumurta dünyada olduğu gibi ülkemizde de sevilerek tüketilen bir gıda maddesidir (Çelebi \& Karaca, 2006). $\mathrm{Bu}$ nedenle dünyada yumurta üretimi yaygın olarak ve yüksek bir seviyede gerçekleştirilmektedir. Ayrıca yıl bazında yumurtanın üretim değerleri gittikçe artmaktadır (Çiçekgil, 2014).

Yumurtaya olan ilgilin fazla olması ağırlığının hassas ve hızlı olarak ölçülerek, doğru ağırlık sınıfının belirlenmesi gerekliliğini doğurmuştur. Çünkü yumurtalar kutuların üzerinde yazan ağırlık sınıfına uygun olarak paketlenerek satılmaktadır. Yapılan araştırmalar ise geleneksel tüketicilerin yumurtanın ağırlığına dikkat ettiğini göstermektedir (Çelik \& Şengül, 2001). Bundan dolayı üretici firmanın doğru sınıflandırma yaparak yumurtaları paketlemesi müşteri gözündeki kalite 
algısını arttıracak ayrıca firma maliyetlerine de doğrudan bir etki oluşturacaktır. Bu nedenle yumurtanın ağırlığına göre olması gerekenin altında sınıflandırılması, üretici firmaya ekstra bir maliyete yol açarken daha üzerinde bir sınıflandırma gerçekleştirilmesi ise müşteri memnuniyetsizliğine neden olmaktadır.

Tavuk üretiminde de yumurta ağırlığının tespit edilmesi önemli bir yere sahiptir. Çünkü yapılan araştırmalar yumurta ağırlığı ile kuluçka performansı arasında yakın bir ilişki olduğunu göstermiştir (Gonzalez, Satterlee, Moharer \& Cadd , 1999; Wilson, 1991).

Bu çalışmada diğer bir uygulama örneği olarak portakal seçilmiştir. Çünkü portakalın ağırlığının hesaplanması sürecinde kullanılan yöntem ile diğer meyvelerin ve sebzelerin ağırlıklarının hesaplanmasında kullanılacak olan yöntem benzerlik göstermektedir. Bu nedenle portakal örneklerinin kullanılması, ileride diğer meyve ve sebzeler için de ağırlık tahmininin yapılabilmesinde kolaylık sağlayacaktır.

Ağırlık tahmin işlemi sırasında dama tahtası görüntüsü kullanılarak, uzaklıktan ve kamera açısından bağımsız çalışan ve böylelikle kullanıcı kaynaklı hataların minimize edilmesinin sağlandığı bir sistem elde edilmiştir. Yumurta üzerinde yapılan çalışmalarda sistemin eğitilmesi ve test edilmesi için 4 farklı markadan 4 farklı sınıfta (çok büyük - büyük - orta - küçük) 250 adet örnek yumurta kullanılmıştır. Portakal üzerinde yapılan çalışmalarda ise farklı büyüklüklerde 150 adet portakal örneği kullanılmıştır. Yumurta için negatif, pozitif ve dik açılı olmak üzere 750 adet görüntü, portakal için de negatif, pozitif ve dik açılı olmak üzere 450 adet görüntü içeren bir veri tabanı oluşturulmuştur. Ayrıca, bu ağırlık tahmin sistemi Şalvarcı ve Ayten (2017) tarafından ilk olarak yumurta objesi için MLP kullanılarak gerçekleştirilmiş ve sistemin başarımı hesaplanmıştır. Benzer şekilde Şalvarcı (2017) aydınlatıcı, yansıtıcı ve kameradan oluşan sistemde 250 yumurta örneği kullanılmıştır. Bu sistemin korelasyon katsayısı \%99.42 olarak elde edilmiştir. Bu çalışmada, farklı olarak yumurta ve portakal objeleri kullanılmış ayrıca MLP ve radyal tabanlı fonksiyon (radial basis function - RBF) kullanılarak ağırlık tahmini gerçekleştirilmiştir Şalvarc1 (2017).

\section{Yapay Sinir Ağları}

YSA'ların temel işleme birimlerine nöron adı verilmektedir. Şekil 1'de örnek bir nöron diyagramı gösterilmektedir. Burada girdi değerleri, ilgili ağırlık ile çarpıldıktan sonra toplama fonksiyonuna iletilmektedir. Toplama fonksiyonuna iletilen değerler (1) eşitliğindeki gibi lineer olarak toplanmaktadır.

$v=w_{1,1} \cdot x_{1}+w_{1,2} \cdot x_{2}+\cdots+w_{1, m} \cdot x_{m}+b=w \cdot x_{\text {toplam }}+b$

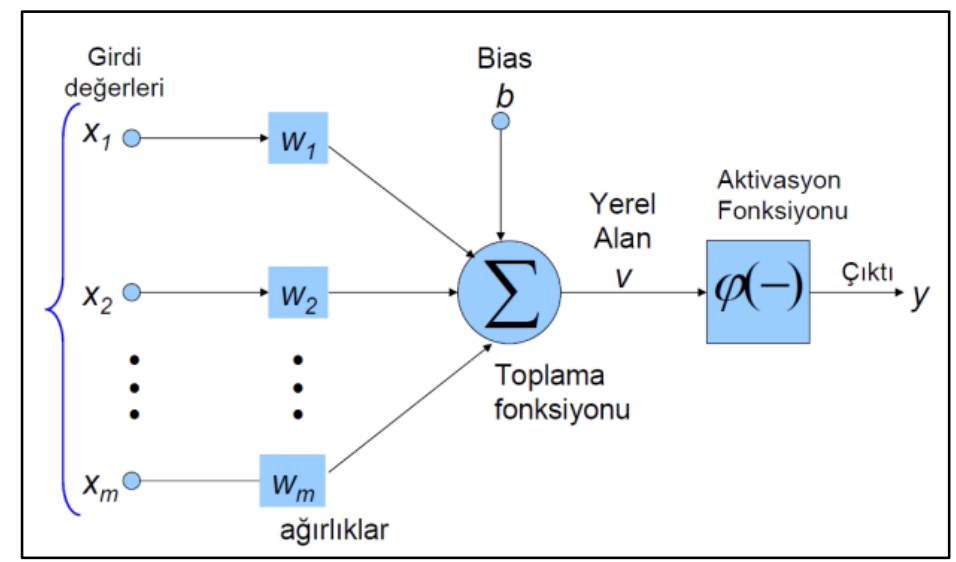

Şekil 1: Lineer olmayan nöron modeli (URL-2) 
Bias değeri ile de aktivasyon fonksiyonuna uygulanacak olan girişin azaltılması ve arttırılması sağlanabilmektedir. Son olarak, elde edilen çıktı aktivasyon fonksiyonuna uygulanmakta ve nöronun çıktısı elde edilmektedir. Bu çıktı (2) eşitliğinde gösterilmiştir (Haykin, 1994).

$y=f\left(w \cdot x_{\text {toplam }}+b\right)$

Daha sonra girdilerin ve beklenen çıktı ile elde edilen çıktının arasındaki farkın, öğrenme oranıyla $(\alpha)$ çarpılarak ağırlık değerlerine eklenmesiyle öğrenme işlemi gerçekleştirilmektedir.

Tek katmanlı algılayıcılar (single layer perceptron - SLP) 1958 yılında tanımlanmıştır. SLP’ler tek katmandan oluşan ve eğitilebilir ağırlığı bulunan ağlardır ve sadece doğrusal olan problemlere çözüm üretebilmektedir. Tek katmanlı algılayıcı blok diyagramı Şekil 2'de gösterilmektedir.

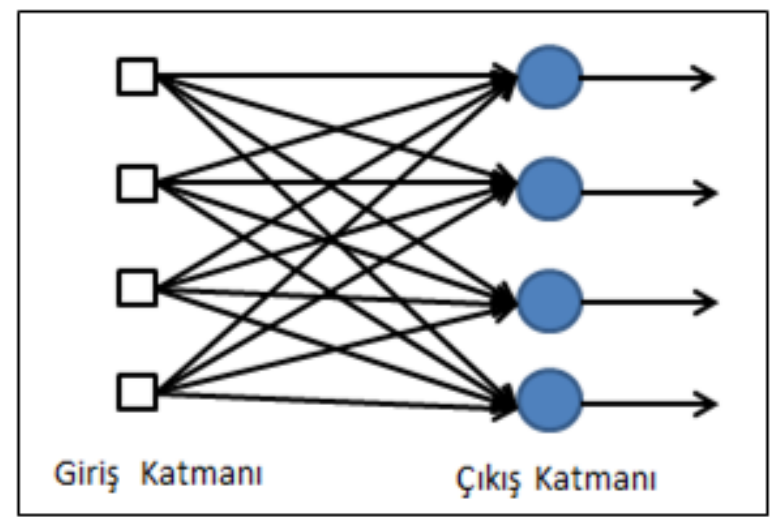

Şekil 2: Tek katmanlı algılayıcı

Daha sonra doğrusal olmayan problemlerin çözümüne ihtiyaç duyulmasından dolayı MLP'ler bulunmuştur. MLP'ler giriş katmanı, gizli katman ve çıkış katmanı olmak üzere 3 katmandan oluşan ağlardır. Giriş katmanında veriler alınarak gizli katmana iletilmektedir. MLP blok diyagramı Şekil 3'te gösterilmektedir. Gizli katmanda bulunan nöron sayısı ve gizli katman sayısı probleme göre değişkenlik göstermektedir. Gizli katman sayısı ve gizli katmandaki nöron sayısı belirlenirken çoğu zaman sabit matematiksel metotlar kullanılamamakta, sezgisel bir şekilde bu değerler belirlenmektedir. Son olarak gizli katmandan gelen veriler çıkış katmanında işlenerek, YSA’nın çıktısı elde edilmektedir (Haykin, 1994; Kriesel, 2005).

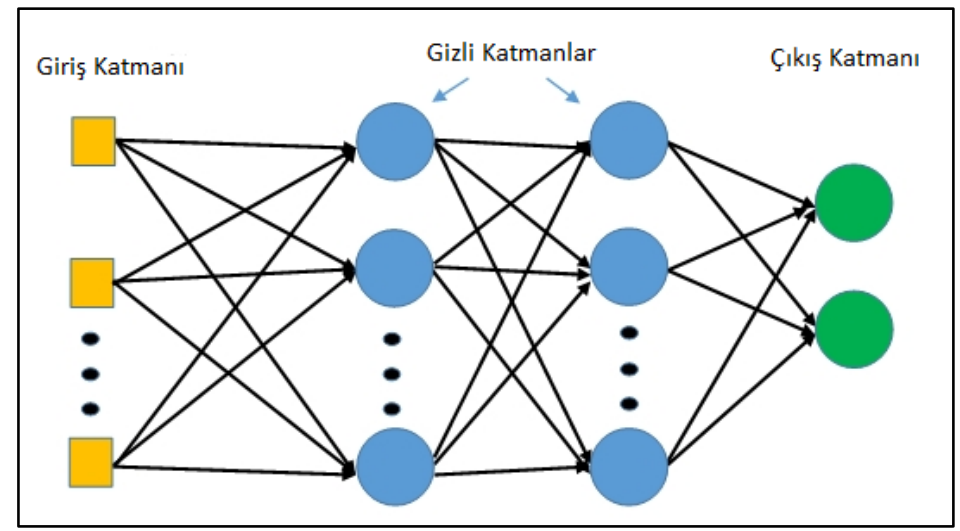

Şekil 3: Çok katmanlı algılayıcı (URL-3)

RBF ağı da MLP'ler gibi 3 katmandan oluşmaktadır. Bu katmanlar aynı şekilde giriş katmanı, gizli katman ve çıkış katmanıdır; fakat RBF’lerde 1 adet gizli katman bulunmaktadır. RBF’ler ileri beslemeli ağlardır ve bütün katmanlar birbirine 
bağlıdır. Giriş katmanı gizli katmana ağırlıksız olarak bağlanmıştır. Bu nedenle ağa uygulanan başlangıç koşullarından çok fazla etkilenmemektedir (Kriesel, 2005). RBF ağı blok diyagramı Şekil 4’te gösterilmektedir.

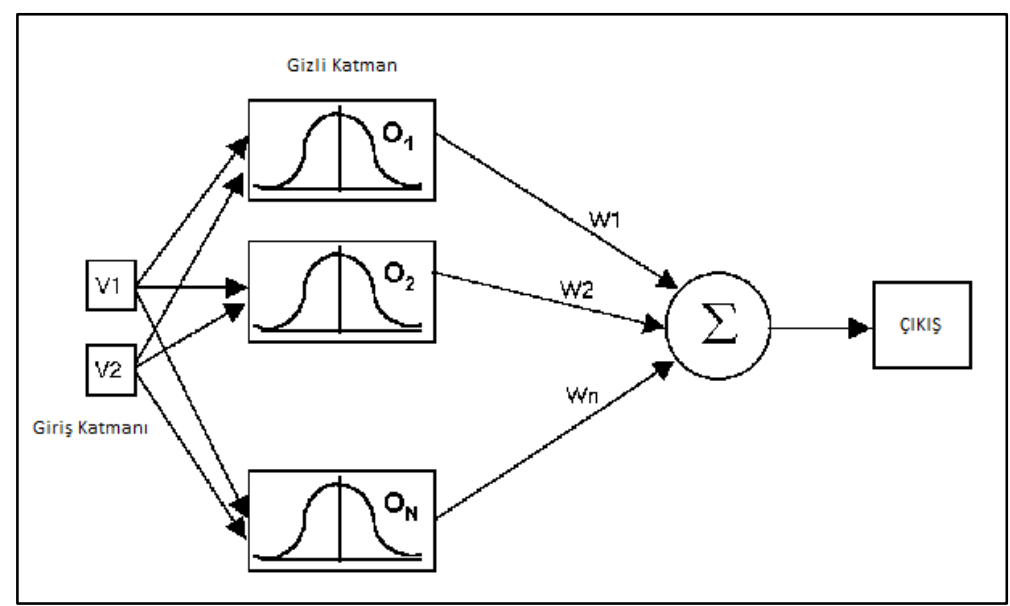

Şekil 4: Radyal temelli fonksiyon ağı (URL-4)

\section{Materyal ve Metot}

Bu bölümde sınırlı çerçevede uzaklıktan bağımsız olarak objelerin ağırlıklarının tahmin edilmesi işlemi sırasında kullanılan materyal ve metotlar ayrıntılı olarak verilmiştir.

\section{1 Ölçüm Düzeneği ve Kameranın Kalibrasyonu}

Uzaklıktan ve kamera açısından sınırlı çerçevede bağımsız çalışabilen ve alınacak olan görüntülerin ışık değişimlerinden minimum düzeyde etkileneceği bir ölçüm düzeneği oluşturulmuştur. Görüntü verilerinin düzgün alınabilmesi için kamera kalibrasyonu ve görüntü dönüşümleri gerçekleştirilmiştir. Bu bölümde bu işlemler sırasıyla verilecektir.

\subsection{1 Ölçüm Düzeneği}

Ağırlığı ölçülecek objenin ve referans görüntünün tam olarak belirlenebilmesi amacıyla ölçüm düzeneği oluşturulmuştur. Oluşturulan ölçüm düzeneği bir adet doğrusal 1şık, yansıtıcılar, referans görüntü ve kameradan oluşmaktadır. Yansıtıcılar doğrusal 1şığ1 yansıtarak objenin ve referans görüntünün belirlenmesi ve öznitelik vektörlerinin çıkarılması aşamasında 1şık yetersizliğinden dolayı oluşacak hataları minimize etmek amacıyla kullanılmıştır. Referans görüntü ile de sınırlı çerçevede kamera açısından ve uzaklığından bağımsız olarak ağırlık tahmin işlemi gerçekleştirilmektedir. Oluşturulan ölçüm düzeneği Şekil 5 'te gösterilmiştir.

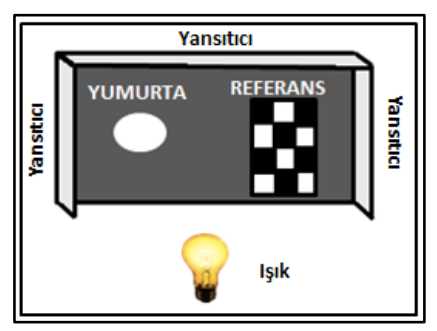

Şekil 5: Ölçüm düzeneği

\subsubsection{Kameranın Kalibre Edilmesi}

Objelerin ağırlıklarının tahmin edilmesi sırasında objelerin görüntüleri tek bir kamera kullanılarak elde edilmiştir. Kamera 
olarak 4. nesil Ipad kamerası kullanılmıştır. Bu kamera 2592x1936 piksel çözünürlüğüne sahiptir. Kamera kalibrasyonu MATLAB programı ile yapılmıştır. Tek bir kamera ile görüntülerin elde edilmesi nedeniyle kalibrasyon işlemi sırasında “MATLAB SINGLE CALIBRATION APP” kullanılmıştır. Kamera parametreleri genellikle iç yöneltme ve dış yöneltme parametreleri olarak ikiye ayrılmaktadır. İç yöneltme elemanları asal noktanın konumu ve kameranın odak uzaklı̆̆ııır. Dış yöneltme parametrelerinden olan izdüşüm merkezi, üç boyutlu koordinat sisteminde belirlenmektedir. Objelerin koordinatları ise 3 boyutlu olarak kamera merkezli koordinat düzlemine göre dönüştürülmektedir (Heikkila \& Silven, 1997). Gerçekleştirilen bu çalışmada da kullanılan kameranın iç yöneltme, dış yöneltme ve distorsiyon parametreleri incelenmiştir ve bu parametrelerin değerlerine göre uygun kalibrasyon işlemi gerçekleştirilmiştir (Kraus, 2007). Kalibrasyon işlemi sırasında 10x7'lik dama tahtası (checkerboard) görüntüsü kullanılmıştır. Kalibrasyon için kullanılan örnek bir dama tahtası görüntüsü Şekil 6'da gösterilmiştir.

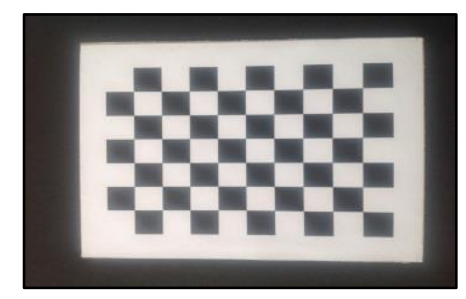

Şekil 6: Kullanılan dama tahtası görüntüsü

Farklı açılardan elde edilmiş 38 farklı dama tahtası görüntüsü MATLAB içerisine aktarılmıştır. Kalibrasyon sırasında bu görüntülerden bazıları reprojeksiyon hatası ve kamera dış yöneltme parametreleri baz alınarak sistemden çıkarılmıştır. Reprojeksiyon hatası, elde edilen değer ile beklenen değer arasındaki piksel farkından kaynaklanan ortalama hatadır (Hartley \& Zisserman, 2003). Reprojeksiyon hatası 1.1 pikselden büyük olan görüntüler ile kamera dış yöneltme parametreleri incelendiğinde dama tahtası görüntüsünün kamera koordinatına göre yanlı̧ konumlandığı tespit edilen görüntüler hatalı olarak değerlendirilerek kamera kalibrasyonuna dahil edilmemiştir. Bu kontroller sonucunda 6 görüntü çıkarılarak, kalan 32 görüntü ile kameranın kalibrasyon işlemi tamamlanmıştır.

\subsubsection{Görüntü Dönüşümleri}

Kameranın, ölçüm düzeneğinde sabit bir mesafede ve sabit bir açı ile yer almamasından dolayı görüntü dönüşümlerinin yapılması gerekmektedir. Öncelikli olarak merkez noktası referans alınarak saat yönünün tersine görüntünün belirli bir açıda döndürülmesiyle görüntü sisteme uygun hale getirilmektedir. Sonraki aşamada ise bütün görüntüler normalize edilmektedir. Objelerin ağılıklarının tahmin edilmesi işleminde uzaklıktan ve kamera açısından bağımsız olması nedeniyle kameranın koordinatları $(x, y, z)$ farklılık göstermektedir. Ayrıca tek bir kameranın kullanılmasına rağmen dik, negatif ve pozitif açılar ile objenin görüntüleri elde edilmiştir. Bu nedenle kamera koordinatlarından kaynaklanan, perspektif görüntüde oluşacak olan farklılıkların giderilmesi gerekmektedir. Kamera koordinatının, görüntünün elde edilmesi aşamasında tam dik bir iz düşüm oluşturacak şekilde normalize edilmesi amacıyla projektif dönüşüm uygulanmıştır. 8 parametreli projektif dönüşüm ile görüntü düşeye çevrilmektedir. Eşitlik 3 ve 4'de gösterildiği gibi her bir nokta için iki eşitlik yazılmalıdır. Objenin koordinatları $x^{\prime \prime}$ ve $y^{\prime \prime}$ ile görüntü koordinatları ise $x^{\prime}$ ve $y^{\prime}$ ile gösterilmektedir. Bilinmeyen parametreler ise $a, b, c, d, e, f$, $g, h$ ile gösterilmektedir ve 8 farklı eşitlik ile bu parametreler hesaplanmaktadır (Aydar, 2007).

$x^{\prime \prime}=\frac{a \cdot x^{\prime}+b y^{\prime}+c}{g^{\prime} \cdot x^{\prime}+h \cdot y^{\prime}+1}$

$y^{\prime \prime}=\frac{d \cdot x^{\prime}+e y^{\prime}+f}{g^{\prime} \cdot x^{\prime}+h \cdot y^{\prime}+1}$ 
Projektif dönüşüm referans görüntü yardımıyla gerçekleştirilmektedir. Öncelikli olarak referans görüntü olarak kullanılan dama tahtası görüntüsünün referans noktaları ve boyutu belirlenmektedir. Belirlenen bu değerler ve beklenen değerler arasındaki farklar ile görüntüye uygulanacak olan geometrik dönüşüm hesaplanmıştır. Son olarak belirlenen geometrik dönüşüm, görüntüye uygulanarak görüntü dönüşümleri tamamlanmaktadır.

\subsection{Belirlenen Öznitelik Vektörleri}

Sistem performansı belirlenirken ve ağırlık tahmin işlemi sırasında, ağırlığı tahmin edilecek objelerin öznitelik vektörlerinden yararlanılmaktadır. Öznitelik vektörleri objelerin kendine özgü karakteristik özellikleridir ve bu nedenle objeden objeye bu karakteristik özellikler değişmektedir. Öznitelik vektörlerini doğru olarak belirlemek sistem performansını önemli ölçüde etkileyen en kritik parametrelerden biridir. Genel olarak öznitelik vektörlerinin belirlenmesi aşamasında belirli matematiksel metotlar kullanılamamaktadır. Bu aşamada sezgisel yaklaşım kullanılmakta ve dolayısıyla tasarımcının tecrübesi oldukça önem kazanmaktadır (Çölkesen, 2009).

Objelerin ağırlıkları tahmin edilirken, belirlenmiş olan öznitelik vektörleri sistemin girişine uygulanmakta ve sistemin çıkış değeri ilgili objenin tahmini ağırlı̆̆ını vermektedir.

Farklı öznitelik vektörleri ile farklı başarımlar elde edileceği için farklı öznitelik vektörleri test edilmiş ve test edilen öznitelik vektörlerine göre başarımlar ilerleyen bölümlerde açıklanmıştır.

Sistemde kullanılan öznitelik vektörleri;

A) Objenin Yüzey Alanı: Ağırlığı ölçülecek olan obje ve referans görüntü tespit edildikten sonra kapladıkları alanlar piksel değeri cinsinden hesaplanmaktadır. Referans görüntüdeki kareler 2 boyutlu görüntü koordinatları ( $x$, $y$ ) şeklinde tanımlanmıştır. Birinci siyah karenin diğer siyah kare ile kesişim noktası $\left(x_{i}, y_{i}\right)$, sağ üst köşedeki siyah karenin diğer siyah kare ile kesişim noktası $\left(x_{l}, y_{l}\right)$, sol alt köşedeki beyaz karenin diğer beyaz kare ile kesişim noktası $\left(x_{k}, y_{k}\right)$ ile gösterilmektedir. Referans görüntüdeki karelerin kenar uzunlukları k ile yatayda bulunan siyah ve beyaz kare sayısı $d_{x}$ ile ve dikeyde bulunan siyah ve beyaz kare sayısı $d_{y}$ ile tanımlanmıştır. Bu parametreler yardımıyla $r a$ ve $r b$ değerlerini veren ifadeler (5) ve (6)'da gösterilmiştir. Bu değerlerin çarpılması ile de (7)'de gösterilen dönüşüm katsayısı $(\sigma)$ elde edilmektedir. Dönüşüm katsayısı ile ağırlığı tahmin edilecek objenin piksel değeri çarpılarak $\mathrm{cm}^{2}$ cinsinden alan hesaplanmaktadır.

$$
\begin{aligned}
& r a=((d x-1) \times k) \div\left[\left(x_{i}-x_{l}\right)^{2}+\left(y_{i}-y_{l}\right)^{2}\right]^{-\frac{1}{2}} \\
& r b=((d y-1) \times k) \div\left[\left(x_{i}-x_{k}\right)^{2}+\left(y_{i}-y_{k}\right)^{2}\right]^{-\frac{1}{2}} \\
& \sigma=r a \times r b
\end{aligned}
$$

B) Objenin Çevresi: Ağırlığg tahmin edilecek objenin çevresi, piksel değerinde hesaplanmakta ve cm’ye dönüştürülmektedir. Dönüştürme işlemi sırasında dönüşüm katsayısı $(\rho)$ ile objenin çevresinin piksel değeri çarpılmaktadır. Dönüşüm katsayının hesaplanması (8)'de gösterilmiştir.

$\rho=\frac{r a+r b}{2}$

C) Merkeze En Uzak Kenar Noktası (MEUKN): Ağırlığı tahmin edilecek objenin merkez noktası $\left(x_{m}, y_{m}\right)$ ile objenin sınır noktaları ise $\left(x_{n}, y_{n}\right)$ ile gösterilmektedir. Objenin sınırları belirli sayıda $t$ adet tam sayıdan oluşacak şekilde belirlenerek, her 
bir sınır noktası için merkeze olan Öklid uzaklığı hesaplanmaktadır. Bu Öklid uzaklıklarından en büyüğü merkeze en uzak kenar noktasını vermektedir. En uzak kenar noktasını belirlemek için kullanılan yöntem (9)'da gösterilmiştir.

$\max (d)=\max \left(\left[\left(x_{m}-x_{n}\right)^{2}+\left(y_{m}-y_{n}\right)^{2}\right]^{-\frac{1}{2}}\right.$

$n=1,2,3,4, \ldots, t$

D) Merkeze En Yakın Kenar Noktası (MEYKN): En uzak kenar noktasını hesaplama yöntemine benzer şekilde en yakın kenarı hesaplama yöntemi (10)'da verilmiştir. Öklid uzaklıklarından en küçüğü merkeze en yakın kenar noktasını vermektedir.

$\min (d)=\min \left(\left[\left(x_{m}-x_{n}\right)^{2}+\left(y_{m}-y_{n}\right)^{2}\right]^{-\frac{1}{2}}\right.$

$n=1,2,3,4, \ldots, t$

E) Yuvarlaklık: Yuvarlaklık öznitelik vektörünün hesaplanma yöntemi (11)’de gösterilmiştir.

$R=\frac{\min (d)}{\max (d)}$

\subsection{Veri Tabanı}

Oluşturulan sistemde bir adet veri tabanı bulunmaktadır. Bu veri tabanı portakal ve yumurta verileri için iki farklı tabloya sahiptir. Veri tabanı bünyesindeki ilgili tablolarda; sistemin eğitilmesi, test edilmesi ve doğrulanması için kullanılan yumurta ve portakal örneklerinin 3 farklı açıdan çekilmiş görüntüleri, her bir görüntü için öznitelik vektörü değerleri ve bu örneklerin hassas tartı ile ölçümleri sonucunda elde edilen ağırlıkları yer almaktadır. Bu veri tabanına bilgi aktarım sürecini gösteren akış diyagramı Şekil 7'de verilmiştir.

Yumurta ve portakal örneklerinin görüntüleri tek bir kamera ile pozitif, negatif ve dik açı olacak şekilde 3 farklı açıdan elde edilmiştir. Bu açılar Şekil 8'de gösterilmiştir. Üç farklı açıdaki kamera konumları ise her bir obje için değişkendir. Bu açılar, sistemin farklı açılardan elde edilen görüntülere göre başarımını değerlendirmek ve optimum sistem parametrelerinin bulunması amacıyla kullanılmıştır. Her bir açı için de 5 temel öznitelik vektörü hesaplanmakta, toplamda ise 15 öznitelik vektörü sisteme farklı kombinasyonlarda uygulanmaktadır. Farklı açılardan elde edilmiş bu görüntüler aynı anda veya ayrı ayrı sisteme uygulanarak sistem başarımı ölçülmüştür. Bu yöntemle tek bir kamera kullanılmasından kaynaklı hataların minimize edilmesi amaçlanmıştır. Ayrıca veri tabanı içerisindeki her bir görüntüde referans görüntü de bulunmaktadır. Buna ek olarak veri tabanına eklenecek yumurta ve portakal örnekleri seçilirken objelerin farklı boyutlarda ve farklı ağırlıklarda olmasına dikkat edilmiştir. Kurulan ağırlık tahmin sisteminin veri tabanında bu özelliklerde 1200 adet görüntü, her bir görüntü için 5 temel öznitelik vektör değeri ve hassas tartı ile ölçülmüş ağırlık değeri bulunmaktadır.

\subsubsection{Kullanılan Portakal Örnekleri}

Veri tabanına, 150 farklı portakal örneğinin 3 farklı açıdan elde edilmiş 450 adet görüntüsü eklenmiştir. Bu örnekler belirlenirken farklı ağırlıklarda, farklı büyüklük ve şekillerde olmasına dikkat edilmiştir. Hassas tartı ile ölçülerek veri tabanına eklenen portakal örneklerindeki en hafif portakal 89 gr ve en ağır portakal 178 gr'dır. Portakalların ortalama ağırlık değeri ise 119.9 gr olarak hesaplanmıştır.

\subsubsection{Kullanılan Yumurta Örnekleri}

Veri tabanına eklenmek üzere 250 adet yumurta örneği kullanılmıştır. Bu yumurta örnekleri seçilirken farklı boyutlarda ve farklı ağırlıklarda olmasına dikkat edilmiştir. Ayrıca sınıflandırma başarımının tek bir marka özelinde değerlendirilmemesi 
için 4 farklı marka tarafından piyasada satılan yumurtalar tercih edilmiştir.

Paket üzerinde yazan sınıflandırma değerlerine göre 60 adet çok büyük, 90 adet büyük, 40 adet orta, 60 adet küçük boyutta yumurta satın alınmıştır. Yumurta ağırlıklarının sınıflandırılması Türk Gıda Kodeksi Yumurta Tebliği’ne göre yapılmaktadır. Satın alınan yumurta örneklerinin hassas tartı ile ölçülmesi sonucunda, Türk Gıda Kodeksine göre 9 adet çok büyük, 103 adet büyük, 89 adet orta, 49 adet küçük boyutta yumurta olduğu görülmüştür. A sınıfı yumurtaların Türk Gıda Kodeksine göre ağırlık sınıflandırılması Tablo 1'de verilmiştir.

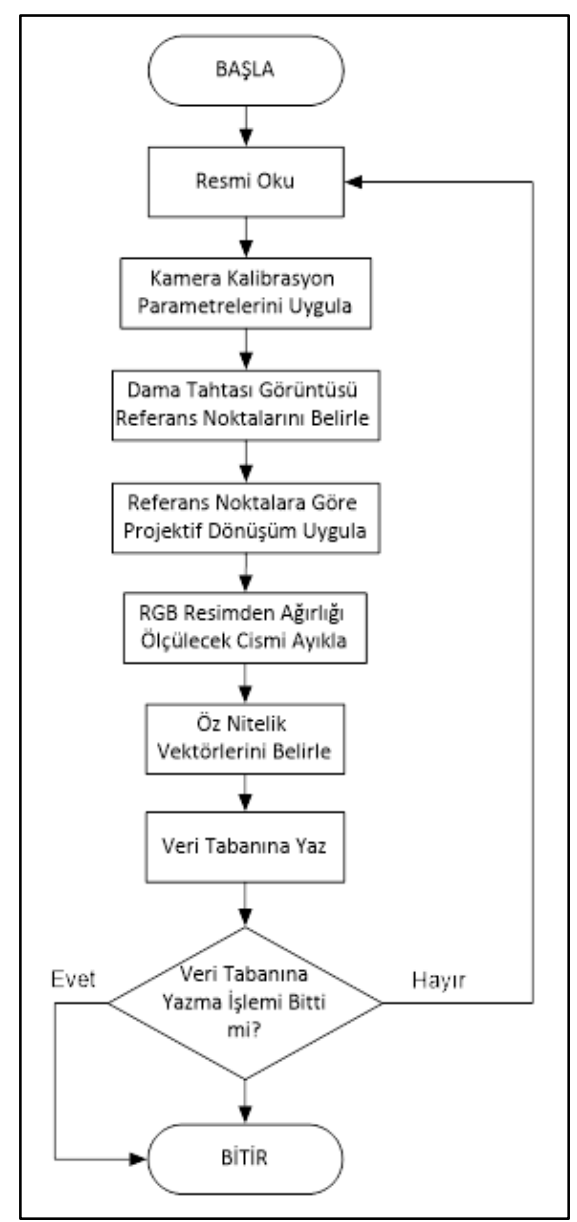

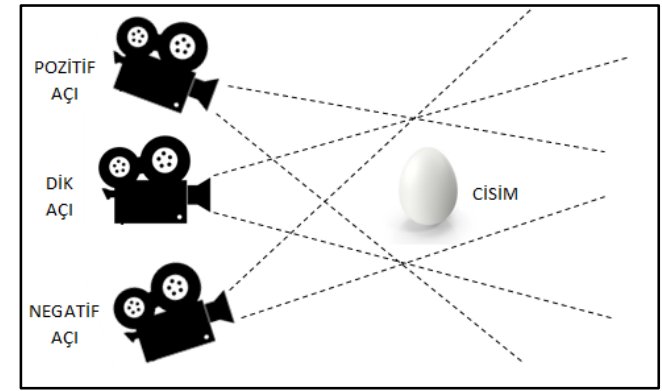

Şekil 8: Kamera açıları

Tablo 1: A sınıfı yumurtalarda ağırlık sınıfları (URL-5)

\begin{tabular}{cc}
\hline Ă̆ırlık Sınıfı & Ă̆ırlık \\
\hline XL-Çok Büyük & $>73$ gr \\
\hline L-Büyük & $>63-<73$ gr \\
\hline M-Orta & $>53-<63$ gr \\
\hline S-Küçük & $<53$ gr \\
\hline
\end{tabular}

Şekil 7: Veri tabanına veri yazma süreci akış diyagramı

Veri tabanına, 3 farklı açıdan elde edilmiş 750 adet yumurta örneği görüntüsü eklenmiştir. Hassas tartı ile ölçülerek veri tabanına eklenen yumurta örneklerindeki en hafif yumurta 32 gr ve en ağır yumurta 75 gr' dır. Yumurtaların ortalama ağırlık değeri ise 60.5 gr olarak hesaplanmıştır.

\subsection{Yapay Sinir Ağları ile Ağırlık Tahmini}

Objelerin ağırlıklarının tahmin edilebilmesi için yapay sinir ağları kullanılmıştır ve bu tahmin işleminin yüksek doğruluk oranı ile gerçekleştirilebilmesi amacıyla MLP ve RBF ağları test edilmiştir. RBF ağının karesel ortalama hata hedefi, ekranlar arasına eklenecek nöron sayısı, yayılma değerleri ve giriş katmanındaki nöron sayıları değiştirilmiştir. MLP'de ise öğrenme katsayısı, iterasyon katsayısı, gizli katman sayısı, gizli katmandaki nöron sayısı, aktivasyon fonksiyonları, öğrenme fonksiyonu gibi parametreler değiştirilmiştir. Ayrıca farklı öznitelik vektörleri ve ağırlığı tahmin edilecek örnek objelerin farklı açıdan elde edilmiş görüntüleri kullanılarak sistemin başarımı hesaplanmıştır. 


\subsubsection{Sistem Başarımının Hesaplanması}

Sistemin başarımı hesaplanırken veri tabanında bulunan portakal ve yumurta örneklerini içeren tablolar rastgele olarak \% 70’i eğitim, \%15'i test ve \%15'i doğrulama işlemi için bölünmüştür. Kurulmuş olan sistemin eğitilmesi, test edilmesi ve doğrulanması aşamasında rastlantısal olarak veri kümelerinin oluşturulması sistem başarımının belirlenmesinde de bir belirsizliğe yol açmaktadır. Bu belirsizliği gidermek için rastgele olarak belirlenen bu veri kümeleri 5'er kez sisteme uygulanarak, her bir uygulama için ortalama mutlak hata (mean absolute error - MAE) ve korelasyon katsayısı ( $R$ ) değerleri elde edilmektedir. Elde edilen bu değerlerin aritmetik ortalaması ilgili veri kümesinin başarımını oluşturmaktadır. Sistem başarımı ise sisteme uygulanan eğitim, test ve doğrulama verilerinin içinde bulunduğu genel veri kümesinin MAE ve R değer ortalamaları ile hesaplanmaktadır. Buna ek olarak; eğitim verisinin az olduğu durumlarda da başarımı en yüksek olan denemenin verdiği tepkinin ölçülebilmesi için, eğitim, test ve doğrulama oranları değiştirilerek sistem başarımı tekrar hesaplanmıştır. Son olarak da K-katlı çapraz doğrulama yöntemi (KKÇDY) uygulanmış böylece veri kümesindeki eğitim, test ve doğrulama verilerinin rastlantısal olarak oluşturulmasından kaynaklı hataların minimize edilmesi sağlanmıştır.

\subsubsection{K-Katlı Çapraz Doğrulama Yöntemi}

Yapılan çalışmalar, KKÇDY ile elde edilen sonuçların, veri kümesinin oluşturulması sırasında kullanılan rastlantısallıktan etkilenme oranının azaldığını göstermiştir (Kohavi, 1995).

Elde edilen veri kümesi, KKÇDY'de k adet, yaklaşık olarak eşit büyüklüklerde alt kümelere bölünmektedir. Bu alt kümelerden k-1 tanesi sistemi eğitmek için kullanılmakta, geriye kalan diğer alt küme ise sistemi test etmek için kullanılmaktadır. Bu yapıyı gösteren ve k=3 için oluşturulmuş örnek veri seti Şekil 9'da gösterilmiştir.

\begin{tabular}{|c|c|c|c|}
\hline$k=1$ & TEST & ЕĞітім & ЕĞітім \\
\hline$k=2$ & ЕĞітім & TEST & ЕĞітім \\
\hline$k=3$ & ЕĞітім & ЕĞітім & TEST \\
\hline
\end{tabular}

Şekil 9: $k=3$ için örnek veri seti

Sistemin başarımı ise, her bir k değeri için oluşturulan veri setinin sisteme uygulanmasıyla hesaplanmaktadır. Her bir k için elde edilen hata değerinin ortalaması, sistemin genel hata ortalamasını vermektedir. KKÇDY ile elde edilen başarım oranı (12)'de gösterilmiştir (James, Witten, Hastie \& Tibshirani, 2013).

Başarım Oranı $=\frac{1}{k} \sum_{i=1}^{k}$ Ortalama Hata $_{i}$

Gerçekleştirilmiş olan bu çalışmada k=5 olarak seçilerek 5 katlı çapraz doğrulama yöntemi uygulanmıştır.

\subsubsection{Yapay Sinir Ağının Eğitilmesi ve Test Edilmesi}

YSA'nın eğitilmesi ve test edilmesi için ilk olarak veri kümesindeki eğitim ve test verilerinin oranları belirlenmektedir. Her bir görüntünün öznitelik vektörleri ve hassas tartı ile ölçüm sonucunda elde edilen ağırlık değerleri veri tabanında kayıtlı olduğundan sistemi eğitmek için belirlenen veriler veri tabanından okunarak YSA'nın girişine uygulanmaktadır. Veri tabanından okunan, beklenen değer ile YSA’nın çıktısı olarak elde edilen değer karşılaştırılarak sistemi eğitme işlemi gerçekleştirilmektedir. Daha sonra sistemi test etmek için ayrılan veriler ile sistem test edilmektedir. Sistemin eğitilmesi ve test edilmesi sonucunda oluşan hata değeri ise sistemin başarımını oluşturmaktadır. Başarımı en yüksek sistemin kurulması 
amacıyla YSA modeli, YSA parametreleri ve objenin öznitelik vektörleri değiştirilerek, sistemin eğitilmesi ve test edilmesi süreçleri tekrarlanmaktadır. Bu işlemler optimum parametrelere ulaşılana kadar devam etmektedir. Son olarak, elde edilen optimum parametreler ile ağırlık tahmin sistemi oluşturulmuştur. Sistemin eğitilmesi ve test edilmesi süreçlerini içeren akış diyagramı Şekil 10’da verilmiştir.

Ağırlık tahmin sistemi yumurta ve portakal örnekleri için optimum sonuç vermesi amacıyla oluşturulmuştur. Farklı objelerin ağırlıklarının tahmin edilmesi sırasında oluşturulan bu sistem aynı başarımı vermeyebilir. Bu nedenle akış diyagramındaki süreçlerin, farklı objeler için tekrar uygulanarak optimum YSA modelinin, parametrelerinin ve öznitelik vektörlerinin belirlenmesi gerekebilir.

\subsubsection{Ağırık Tahmini}

Başarımı en yüksek olan öz nitelik vektörlerine, YSA modeline ve parametrelerine göre oluşturulan sistemde, objelerin ağırlıkları tahmin edilerek ekranda gösterilmektedir. Ağırlık tahmin etme işlemi için öncelikli olarak ağırlığı tahmin edilecek objenin öznitelik vektör değerlerinin elde edilmesi gerekmektedir. Bu öznitelik vektörlerinin çıkarılması sırasında MATLAB programı kullanılmaktadır. Çıkarılan öznitelik vektörleri ise sistemin girişine uygulanmaktadır. Sistem öznitelik vektörü değerlerine karşılık objenin ağırlığını tahmin ederek ekrana yazdırmaktadır. Ağırlığı tahmin edilecek başka objelerin de olması durumunda bu işlemler tekrarlanmaktadır. Tahmin işlemi akış diyagramı Şekil 11'de verilmiştir.

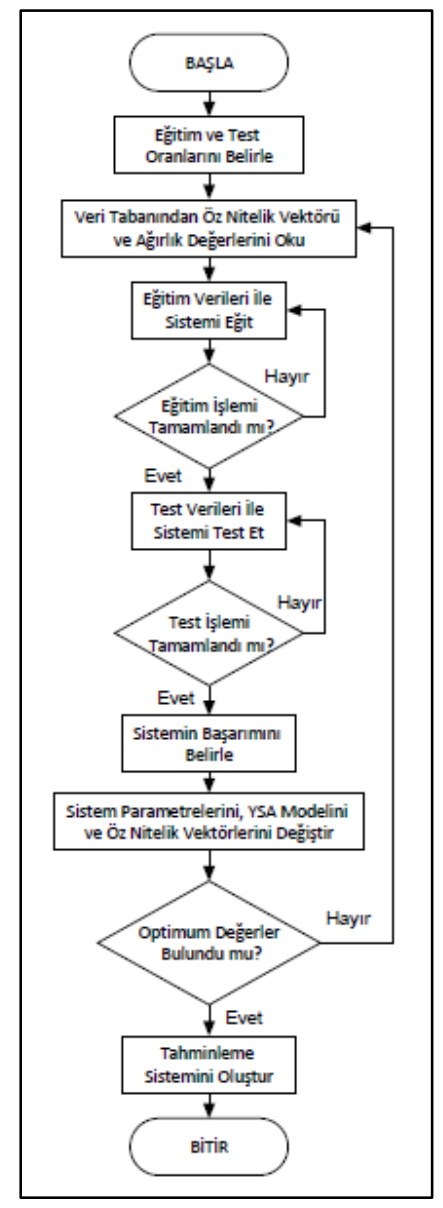

Şekil 10: Sistemin eğitilmesi ve test edilmesi süreci akışı diyagramı

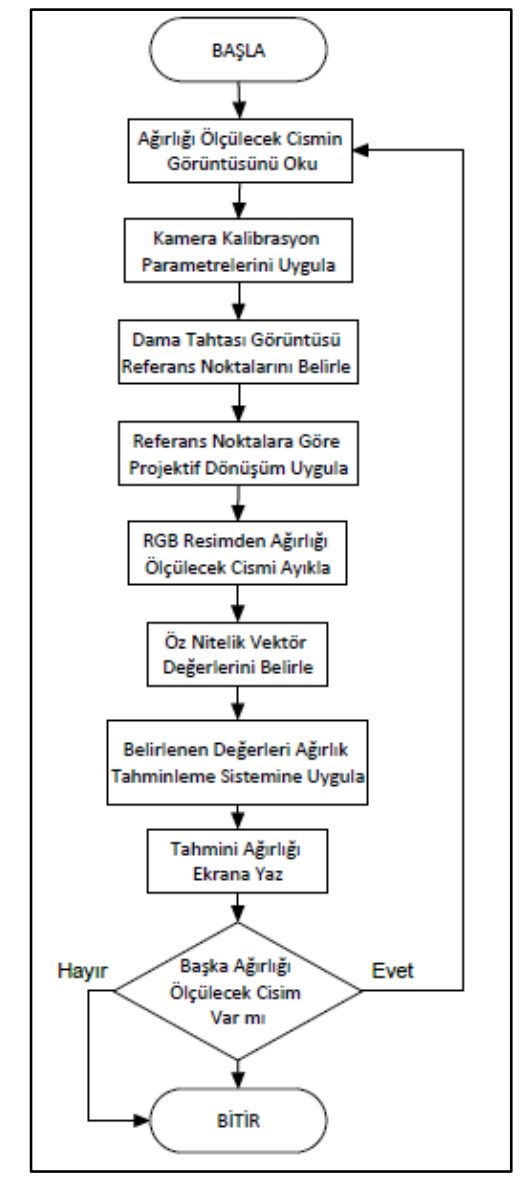

Şekil 11: Tahmin işlemi akış diyagramı

Farklı objelerin ağırlıklarının tahmin edilmesi durumunda ise YSA'nın eğitilmesi ve test edilmesi işlemleri tekrar gerçekleştirilerek ağırlığı ölçülecek obje için başarımı en yüksek sonucu veren sistem parametrelerinin belirlenmesi, sistemin hassasiyetini arttıracaktır. 


\subsection{Objenin Görüntüden Ayrılması}

Objeler görüntüden ayıklanırken iki farklı yöntem kullanılmaktadır. Bunlar, görüntünün piksel piksel incelenerek kod dizilerinin yazılmasıyla oluşturulmuş hassas ölçüm ve MATLAB fonksiyonları kullanılarak oluşturulmuş hızlı ölçümdür. Işı̆̆ın yetersiz olması gibi bazı durumlarda objenin hatalı olarak tespit edilmesinden kaynaklı olarak oluşacak hatalı tahminlerin önüne geçmek amacıyla hassas mod özelliği eklenmiştir. Buna rağmen birçok görüntüde hızlı ölçüm kullanmak yeterli olmaktadır. Objenin ayıklanması sonrasında sınırların belirlendiği örnek görüntü Şekil 12'de gösterilmiş̧ir.

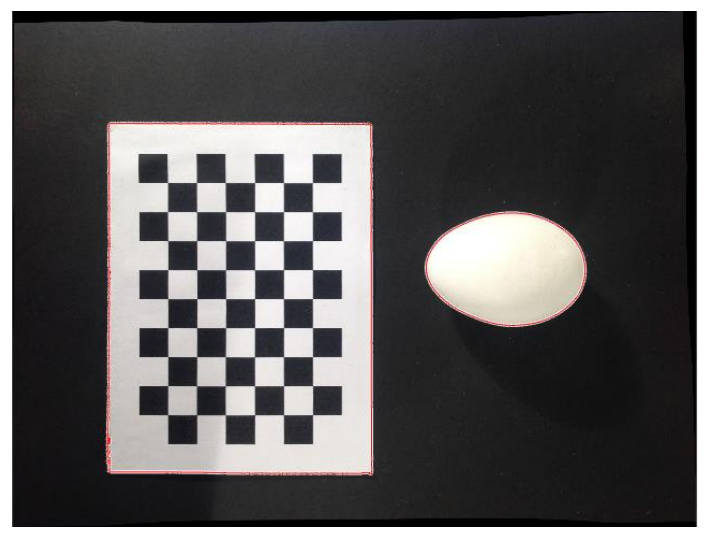

Şekil 12: Objenin sınırlarının belirlendiği örnek görüntü

\subsubsection{Hızlı Ölı̧üm ile Obje Ayıklama Yöntemi}

RGB (Red-Green-Blue) renk formatında sisteme yüklenen görüntüler ton ve saturasyon bilgilerinden bağımsız, parlaklığı korunacak şekilde gri düzeyli görüntüye dönüştürülmektedir. Gri düzeyli renklerin görüntüdeki tekrarlarına bakarak eşik değerinin belirlendiği Otsu metodu kullanılarak eşik değer belirlenmektedir. Belirlenen bu eşik değerine göre görüntü ikili renk formatına dönüştürülmektedir. Daha sonra 10000 pikselden az olan bağlantılı objeler görüntüden silinmektedir. Ayrıca belirlenen ufak hatalar da temizlenmektedir. Son olarak ayıklanan objenin sınır noktaları belirlenerek, başlangıçta yüklenen görüntü üzerinde işaretleme yapılmaktadır.

\subsubsection{Hassas Ölçüm ile Obje Ayıklama Yöntemi}

RGB renk formatında sisteme yüklenen görüntünün piksel değeri "double” veri türüne dönüştürülmektedir. Her bir piksel teker teker incelenmekte, bir alt piksel 0.56 'dan büyük veya pikseldeki 3 rengin (Kırmızı, Yeşil ve Mavi) ortalaması 0.56'dan büyük ise obje var olarak değerlendirilmektedir. Ayrıca, 0.30 'dan büyük bir alt piksel diğer alt piksellerin iki katından büyük ise de "obje var" olarak işaretlenmektedir. Eğer 3 rengin piksel ortalaması 0.25 'ten küçük ise obje yok olarak değerlendirilmektedir. Daha sonra görüntü gri düzeyli görüntüye dönüştürülmekte ve $5 \times 5$ matris boyutundaki gürültüleri temizlemek için medyan filtresi uygulanmaktadır. Sonraki aşamada alt piksel değeri 0.30 'dan büyük olan ve önceki aşamalarda durumu "obje var" ya da "obje yok" olarak değerlendirilememiş pikseller komşu pikseller ile karşılaştırılmaktadır. Bu pikselin, önceki değerlendirme sürecinde "obje var” olarak değerlendirilen piksele komşu olması durumunda ve aralarındaki fark \%10'dan küçük olan komşu alt pikseller var ise (alt pikseller karşılaştırılırken aynı renkteki komşu alt pikseller ile karşılaştırma yapılmaktadır), bu piksel de "obje var" olarak değerlendirilmektedir. Böylelikle objenin sınırları daha hassas belirlenebilmektedir. Daha sonra karar verilememiş piksellerin bulunması durumunda, her bir pikselin RGB bileşenleri için ortalama renk değeri hesaplanarak bir eşik değeri belirlenmektedir. Bu eşik değerin altında kalan pikseller "obje yok" olarak değerlendirilmekte, diğer pikseller ise "obje var" olarak değerlendirilmektedir. Son olarak hızlı ölçüm yöntemindeki gibi 10000 pikselden az olan bağlantılı objeler görüntüden silinmekte, ufak hatalar temizlenmekte ve 
obje görüntü üzerinde işaretlenmektedir.

Buradaki sayısal değerler bulunurken sezgisel yöntem kullanılmıştır. Bu değerler bu çalışmada kullanılan yumurta ve portakal örnekleri için uygulanabilir olmakla birlikte başka problemler için yeni değerlerin bulunması gerekebilir.

\subsection{Kullanıcı Arayüzü}

Kullanıcı arayüzü, başarımı en yüksek sistem parametreleri baz alınarak oluşturulmuştur. Bu sistemde eş zamanlı olarak sadece bir adet objenin ağırlığı tahmin edilebilmektedir. Öncelikle, oluşturulan arayüzde ağırlı̆̆ı tahmin edilecek objenin ne olduğu seçilmelidir. Daha sonra ise ilgili objenin görüntüsü, arayüz aracılığıyla sisteme yüklenmelidir. Ağırlık tahmini sırasında kullanılacak olan YSA yapısı da arayüz üzerinden değiştirilebilmektedir. Ayrıca, hassas ölçüm yapılmak istenirse, hassas mod seçiminin yapılması gerekmektedir. İlgili seçimler yapıldıktan sonra "Ağırlı̆̆ Tahmin Et" butonuna basılarak ağırlık tahmin işlemi gerçekleştirilmekte ve tahmini ağırlık ekrana yazdırılmaktadır. Bu seçimlerden bir tanesinin yapılmaması durumunda, sistem uyarı mesajıyla kullanıcıyı bilgilendirmektedir. Sistem çıktısı olarak; objenin ağırlığının yanı sıra ağırlığı tahmin edilecek objenin ve referans görüntünün sınırları, merkez noktası, merkeze en uzak ve en yakın kenar noktaları, seçilen görüntünün dosya yolu da kullanıcıya sunulmaktadır. Kullanıcı arayüzü ve ağırlık tahmin işlem sonucu için bir örnek Şekil 13'de gösterilmiştir.

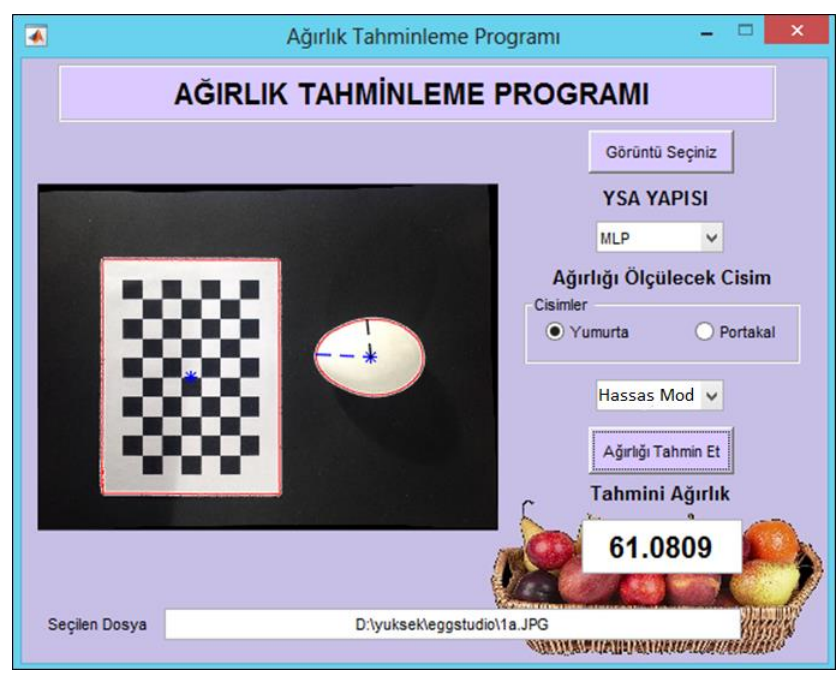

Şekil 13: Kullanıcı arayüzü

\section{Bulgular}

RBF için karesel ortalama hata hedefi, ekranlar arasına eklenecek nöron sayısı, giriş katmanındaki nöron sayıları gibi değerler, MLP için ise öğrenme katsayısı, iterasyon katsayısı, gizli katman sayısı, gizli katmandaki nöron sayısı gibi değerler değiştirilerek farklı denemeler gerçekleştirilmiştir. Her bir deneme için sistem performans değerleri incelenerek başarımı en yüksek sistem oluşturulmuştur.

Performansı en yüksek olan sistem belirlenirken öncelikle eğitim, test ve doğrulama verilerini içeren genel veri kümesinin $R$ değeri baz alınmıştır. Böylelikle bütün veri kümelerinin, sistemin performansı üzerindeki etkisi göz önünde bulundurulmuştur. R değerinin aynı olması durumunda genel veri kümesinin MAE değerine bakılmıştır. Bu değerlerin de aynı olması durumunda sırasıyla test, doğrulama ve eğitim kümelerinin R ve MAE değerlerine bakılarak sistem başarımları belirlenerek denemeler siralanmaktadır. 
Denemeler sezgisel yöntem kullanılarak oluşturulmaktadır. Öncelikli olarak 5 temel öznitelik vektörü farklı kombinasyonlarda sabit YSA parametreleri ile test edilmekte ve en yüksek başarımı veren öznitelik vektörü veya vektörleri belirlenmektedir. Daha sonra ise belirlenen bu öznitelik vektörleri sabit tutularak YSA parametreleri farklı kombinasyonlarda değiştirilmekte ve YSA parametrelerinin sistem performansı üzerindeki etkisi incelenmektedir. Son olarak performansı yüksek olan YSA parametreleri ve temel öznitelik vektörleri sabit tutularak, farklı açılardan elde edilmiş görüntülerin de öznitelik vektörleri sisteme uygulanmakta ve başarımı en yüksek olan sistem elde edilmektedir.

\subsection{Yumurta Simülasyonu}

Yumurta örneği için MLP ile 20 farklı deneme RBF ile 11 farklı deneme gerçekleştirilmiştir. Daha sonra başarımı en yüksek olan sonuçlar için KKÇDY uygulanmıştır. RBF ve MLP için en iyi ağırlık tahmini yapan 5 denemenin birbirlerinden farklı parametreleri sırasıyla Tablo 2 ve Tablo 3 ile verilmiştir. Bu denemelerin sonuçları ise Tablo 4 'te verilmiştir.

Tablo 2: RBF için en başarılı denemelerin parametreleri

\begin{tabular}{cccccc}
\hline Denemeler & D-3 & D-7 & D-2 & D-9 & D-4 \\
\hline Giriş Sayısı & 5 & 4 & 5 & 12 & 5 \\
\hline Temel Öznitelik Vektörleri & 5 & 4 & 5 & 4 & 5 \\
\hline Yayılma Değeri & 100 & 100 & 1 & 100 & 1000 \\
\hline
\end{tabular}

Tablo 3: MLP için en başarılı denemelerin parametreleri

\begin{tabular}{cccccc}
\hline Denemeler & D-19 & D-9 & D-5 & D-8 & D-14 \\
\hline Gizli Katman Nöron Sayıs1 & 40 & 40 & 20 & 20 & 40 \\
\hline Gizli Katman Aktivasyon Fonk. & \multicolumn{2}{c}{ Tanj. Sig. Tanj. Sig. } & Tanj. & Sig. Lineer Tanj. Sig. \\
\hline Çkış Katmanı Aktivasyon Fonk. & \multicolumn{2}{c}{ Tanj. Sig. Tanj. Sig. } & Tanj. Sig. Lineer & Tanj. Sig. \\
\hline Öğrenme Fonksiyonu & GDX & GDX & GDX & GDX & GDA \\
\hline Öğrenme Oranı & 0.5 & 0.1 & 0.5 & 0.1 & 0.5 \\
\hline
\end{tabular}

Tanj. Sig.= Tanjant sigmoid, GDX= Momentum ile gradiyent azalan ve adaptif öğrenme oranlı geri yayllım (gradient descent with momentum and adaptive learning rate backpropagation), GDA= Adaptif öğrenme oranı ile gradiyent azalan geri yayılım.

Tablo 4: RBF ve MLP için denemelerin başarımları

\begin{tabular}{c|ccccc|ccccc} 
& \multicolumn{9}{|c|}{ RBF } & \multicolumn{5}{c}{ MLP } \\
\hline Denemeler & $\mathbf{D - 3}$ & $\mathbf{D}-7$ & $\mathbf{D - 2}$ & $\mathbf{D - 9}$ & $\mathbf{D}-4$ & $\mathbf{D}-19$ & $\mathbf{D - 9}$ & $\mathbf{D}-5$ & D-8 & D-14 \\
\hline Test (MAE) & $0.78 \mathrm{gr}$ & $0.87 \mathrm{gr}$ & $0.84 \mathrm{gr}$ & $0.90 \mathrm{gr}$ & $0.80 \mathrm{gr}$ & $0.90 \mathrm{gr}$ & $0.83 \mathrm{gr}$ & $0.84 \mathrm{gr}$ & $0.79 \mathrm{gr}$ & $0.91 \mathrm{gr}$ \\
\hline Test (R) & 0.9947 & 0.9933 & 0.9936 & 0.9921 & 0.9948 & 0.9916 & 0.9940 & 0.9933 & 0.9945 & 0.9930 \\
\hline Doğrulama (MAE) & $0.88 \mathrm{gr}$ & $0.85 \mathrm{gr}$ & $0.85 \mathrm{gr}$ & $0.77 \mathrm{gr}$ & $0.90 \mathrm{gr}$ & $0.83 \mathrm{gr}$ & $0.83 \mathrm{gr}$ & $0.87 \mathrm{gr}$ & $0.86 \mathrm{gr}$ & $0.84 \mathrm{gr}$ \\
\hline Doğrulama (R) & 0.9921 & 0.9940 & 0.9937 & 0.9953 & 0.9937 & 0.9938 & 0.9943 & 0.9946 & 0.9931 & 0.9935 \\
\hline Eğitim (MAE) & $0.80 \mathrm{gr}$ & $0.79 \mathrm{gr}$ & $0.80 \mathrm{gr}$ & $0.79 \mathrm{gr}$ & $0.82 \mathrm{gr}$ & $0.77 \mathrm{gr}$ & $0.79 \mathrm{gr}$ & $0.79 \mathrm{gr}$ & $0.83 \mathrm{gr}$ & $0.80 \mathrm{gr}$ \\
\hline Eğitim (R) & 0.9945 & 0.9945 & 0.9944 & 0.9944 & 0.9941 & 0.9944 & 0.9941 & 0.9943 & 0.9939 & 9.9940 \\
\hline Genel (MAE) & $0.81 \mathrm{gr}$ & $0.81 \mathrm{gr}$ & $0.81 \mathrm{gr}$ & $0.80 \mathrm{gr}$ & $0.82 \mathrm{gr}$ & $0.80 \mathrm{gr}$ & $0.81 \mathrm{gr}$ & $0.81 \mathrm{gr}$ & $0.83 \mathrm{gr}$ & $0.83 \mathrm{gr}$ \\
\hline Genel (R) & 0.9943 & 0.9943 & 0.9942 & 0.9942 & 0.9941 & 0.9942 & 0.9942 & 0.9941 & 0.9939 & 0.9938 \\
\hline
\end{tabular}

RBF ağının başarımı en yüksek denemeleri için; karesel ortalama hata hedefi 1, ekranlar arasına eklenecek nöron sayısı 25 ve maksimum nöron sayısı giriş vektör sayısına eşit olacak şekilde tanımlanmıştır. Dik açı ile elde edilmiş bütün öznitelik vektörleri "Deneme 3" ve "Deneme 4"te kullanılmıştır. "Deneme 2"de ise "Deneme 3" ve "Deneme 4"ten farklı olarak yuvarlaklık öznitelik vektörünün yerine elips merkezleri ile onların en uzun çap uzunlukları arasındaki oranı veren dışbükeylik (eccenctricity) değeri kullanılmıştır. "Deneme 7”de ise dik açı ile elde edilmiş öznitelik vektörleri; objenin yüzey alanı, objenin çevresi, MEUKN ve MEYKN kullanılmıştır. Bunların yanı sıra, "Deneme 9"da, 3 farklı açıdan elde edilmiş görüntüler için “Deneme 7”de kullanılan bütün öznitelik vektörleri kullanılmıştır.

MLP ağının başarımı en yüksek denemeleri için; tek gizli katman, öğrenme oranı artış miktarı 1.05, öğrenme oranı azalış miktarı 0.7, momentum katsayısı 0.9 (öğrenme fonksiyonu olarak, GDX kullanılan denemelerde uygulanmıştır) ve iterasyon 
sayısı 30000 sabit olarak kullanılmıştır. Ayrıca dik açıyla elde edilmiş görüntülerin; obje yüzey alanı, çevresi ve objenin yuvarlaklık öznitelik vektörleri ortak olarak sisteme giriş gerçekleştirilmiştir.

Veri kümesi 1; \%50'si eğitim, \%25'i test ve \%25'i doğrulama işlemi için bölünerek oluşturulmuştur. Veri kümesi 2 ise \%34'ü eğitim, \%33'ü test ve \%33'ü doğrulama işlemi için bölünmüştür. Bu veri kümelerinin sırasıyla RBF modeli için başarımı en yüksek deneme olan “Deneme 3"e ve MLP için başarımı yüksek deneme olan "Deneme 19"a uygulanması sonucunda elde edilen başarımlar Tablo 5'de verilmiştir.

Tablo 5: RBF ve MLP için veri kümelerinin başarımları

\begin{tabular}{c|cc|cc} 
& \multicolumn{2}{|c|}{ RBF } & \multicolumn{2}{c}{ MLP } \\
\hline Başarım & Veri Kümesi 1 & Veri Kümesi 2 & Veri Kümesi 1 & Veri Kümesi 2 \\
\hline Test (MAE) & $0.84 \mathrm{gr}$ & $0.86 \mathrm{gr}$ & $0.88 \mathrm{gr}$ & $1.01 \mathrm{gr}$ \\
\hline Test (R) & 0.9937 & 0.9937 & 0.9930 & 0.9899 \\
\hline Doğrulama (MAE) & $0.88 \mathrm{gr}$ & $0.87 \mathrm{gr}$ & $0.92 \mathrm{gr}$ & $0.77 \mathrm{gr}$ \\
\hline Doğrulama (R) & 0.9938 & 0.9933 & 0.9929 & 0.9910 \\
\hline Eğitim (MAE) & $0.80 \mathrm{gr}$ & $0.78 \mathrm{gr}$ & $0.79 \mathrm{gr}$ & $0.73 \mathrm{gr}$ \\
\hline Eğitim (R) & 0.9943 & 0.9945 & 0.9943 & 0.9954 \\
\hline Genel (MAE) & $0.83 \mathrm{gr}$ & $0.84 \mathrm{gr}$ & $0.84 \mathrm{gr}$ & $0.91 \mathrm{gr}$ \\
\hline Genel (R) & 0.9940 & 0.9938 & 0.9936 & 0.9922 \\
\hline
\end{tabular}

RBF ağının başarımı en yüksek denemesi “Deneme 3"e KKÇDY, k=5 ve MLP ağının başarımı en yüksek denemesi “Deneme 19"a KKÇDY, k=5 için elde edilmiştir. Sonuçlar Tablo 6'da verilmiştir.

Tablo 6: RBF ve MLP için KKÇDY başarımı

\begin{tabular}{|c|c|c|c|c|c|c|c|c|c|c|c|c|}
\hline & \multicolumn{6}{|c|}{ RBF } & \multicolumn{6}{|c|}{ MLP } \\
\hline & $\begin{array}{c}\text { Test } \\
\text { (MAE) }\end{array}$ & Test (R) & $\begin{array}{l}\text { Eğitim } \\
\text { (MAE) }\end{array}$ & $\begin{array}{c}\text { Eğitim } \\
\text { (R) }\end{array}$ & $\begin{array}{c}\text { Genel } \\
\text { (MAE) }\end{array}$ & $\begin{array}{c}\text { Genel } \\
\text { (R) }\end{array}$ & $\begin{array}{c}\text { Test } \\
\text { (MAE) }\end{array}$ & Test (R) & $\begin{array}{l}\text { Eğitim } \\
\text { (MAE) }\end{array}$ & $\begin{array}{l}\text { Eğitim } \\
\text { (R) }\end{array}$ & $\begin{array}{c}\text { Genel } \\
\text { (MAE) }\end{array}$ & $\begin{array}{c}\text { Genel } \\
\text { (R) }\end{array}$ \\
\hline $\mathrm{k}=1$ & $0.88 \mathrm{gr}$ & 0.9947 & $0.79 \mathrm{gr}$ & 0.9947 & $0.81 \mathrm{gr}$ & 0.9942 & $0.87 \mathrm{gr}$ & 0.9926 & $0.81 \mathrm{gr}$ & 0.9943 & $0.83 \mathrm{gr}$ & 0.9939 \\
\hline $\mathrm{k}=2$ & $0.81 \mathrm{gr}$ & 0.9939 & $0.80 \mathrm{gr}$ & 0.9939 & $0.80 \mathrm{gr}$ & 0.9944 & $0.88 \mathrm{gr}$ & 0.9929 & $0.73 \mathrm{gr}$ & 0.9951 & $0.76 \mathrm{gr}$ & 0.9947 \\
\hline $\mathrm{k}=3$ & $0.80 \mathrm{gr}$ & 0.9943 & $0.82 \mathrm{gr}$ & 0.9943 & $0.80 \mathrm{gr}$ & 0.9943 & $0.80 \mathrm{gr}$ & 0.9942 & $0.83 \mathrm{gr}$ & 0.9942 & $0.82 \mathrm{gr}$ & 0.9942 \\
\hline $\mathrm{k}=4$ & $0.78 \mathrm{gr}$ & 0.9946 & $0.91 \mathrm{gr}$ & 0.9946 & $0.80 \mathrm{gr}$ & 0.9942 & $0.93 \mathrm{gr}$ & 0.9937 & $0.81 \mathrm{gr}$ & 0.9942 & $0.83 \mathrm{gr}$ & 0.9940 \\
\hline $\mathrm{k}=5$ & $0.80 \mathrm{gr}$ & 0.9946 & $0.76 \mathrm{gr}$ & 0.9946 & $0.79 \mathrm{gr}$ & 0.9945 & $0.86 \mathrm{gr}$ & 0.9932 & $0.79 \mathrm{gr}$ & 0.9946 & $0.80 \mathrm{gr}$ & 0.9943 \\
\hline A.O. & 0.81 gr & 0.9944 & 0.82 gr & 0.9944 & 0.80 gr & 0.9943 & 0.87 gr & 0.9933 & $0.79 \mathrm{gr}$ & 0.9945 & 0.81 gr & 0.9942 \\
\hline$\Omega_{-}$ & & 1 & & & & & & & & & & \\
\hline
\end{tabular}

\subsection{Portakal Simülasyonu}

Portakal örneği için MLP ile 21 farklı deneme RBF ile 11 farklı deneme gerçekleştirilmiştir. Daha sonra başarımı en yüksek olan sonuçlar için KKÇDY uygulanmıştır. RBF ve MLP için en iyi ağırlık tahmini yapan 5 denemenin farkı sırasıyla Tablo 7 ve Tablo 8'de verilmiştir.

Tablo 7: RBF için en başarılı denemelerin parametreleri

\begin{tabular}{cccccc}
\hline Denemeler & D-9 & D-10 & D-11 & D-5 & D-7 \\
\hline Giriş Sayıs1 & 12 & 4 & 4 & 5 & 4 \\
\hline Temel Öznitelik Vektörleri & 4 & 4 & 4 & 5 & 4 \\
\hline
\end{tabular}

RBF ağının başarımı en yüksek denemeleri için; yayılma değeri 10 000, karesel ortalama hata hedefi 1, ekranlar arasına eklenecek nöron sayısı 25 ve maksimum nöron sayısı giriş vektör sayısına eşit olacak şekilde tanımlanmıştır. Objenin yüzey alanı, çevresi, MEUKN ve MEYKN öznitelik vektörleri "Deneme 9", "Deneme 10", "Deneme 11" ve "Deneme 7" için 
kullanılmıştır. "Deneme 5" te ise bu öznitelik vektörlerine ek olarak yuvarlaklık öznitelik vektörü de kullanılmıştır. "Deneme 9", "Deneme 10" ve "Deneme 11"de objenin görüntüleri 3 farklı açıdan elde edilmiş diğer denemelerde ise objelerin sadece dik açıyla elde edilmiş görüntüleri kullanılmıştır. "Deneme 9"da farklı açılardan elde edilen bütün görüntüler sisteme uygulanırken, "Deneme 10"da bu görüntülerin geometrik ortalaması alınmıştır. "Deneme 11"de ise bu görüntülerden elde edilen objenin yüzey alanının geometrik ortalaması alınmış, diğer öznitelik vektörlerinin ise aritmetik ortalaması alınmıştır.

RBF için denemelerin başarımları Tablo 9'da verilmiştir.

Tablo 8: MLP için en başarılı denemelerin parametreleri

\begin{tabular}{|c|c|c|c|c|c|}
\hline Denemeler & D-15 & D-21 & D-16 & D-17 & D-19 \\
\hline Giriş Sayısı & 12 & 4 & 4 & 4 & 12 \\
\hline Gizli Katman Nöron Sayısı & 20 & 20 & 20 & 20 & 20 \\
\hline Gizli Katman Aktivasyon Fonk. & \multicolumn{5}{|c|}{ Tanj. Sig. Tanj. Sig. Tanj. Sig. Tanj. Sig. Tanj. Sig. } \\
\hline Çıkış Katmanı Aktivasyon Fonk. & \multicolumn{5}{|c|}{ Tanj. Sig. Tanj. Sig. Tanj. Sig. Ta } \\
\hline Öğrenme Fonksiyonu & GDA & GDX & GDA & GDX & GDX \\
\hline \multicolumn{6}{|c|}{$\begin{array}{l}\text { Tanj. Sig.= Tanjant sigmoid, GDX = Momentum ile gradiyent azalan ve adaptif ögrenme oranl } \\
\text { geri yayılım (gradient descent with momentum and adaptive learning rate backpropagation), } \\
\text { GDA= Adaptif ögrenme oranı ile gradiyent azalan geri yayılım. }\end{array}$} \\
\hline
\end{tabular}

MLP ağının başarımı en yüksek denemeleri için; tek gizli katman, öğrenme oranı 0.5, öğrenme oranı artış miktarı 1.05, öğrenme oranı azalış miktarı 0.7, momentum katsayısı 0.9 (öğrenme fonksiyonu olarak, GDX kullanılan denemelerde uygulanmıştır) ve iterasyon sayısı 30000 sabit olarak kullanılmıştır. Objelerin görüntüleri ise 3 farklı açıdan elde edilmiştir. Bu 3 farklı açıdan elde edilen görüntülerin öznitelik vektörleri "Deneme 15" ve "Deneme 19" için sisteme direk olarak uygulanmıştır. "Deneme 21" ve "Deneme 17”de bu görüntülerden elde edilen objenin yüzey alanının geometrik ortalaması alınmış, diğer öznitelik vektörlerinin ise aritmetik ortalaması alınmıştır. "Deneme 16"da ise bu görüntülerin geometrik ortalaması alınmıştır. MLP için denemelerin başarımları Tablo 9'da verilmiştir.

Tablo 9: RBF ve MLP için denemelerin başarımları

\begin{tabular}{|c|c|c|c|c|c|c|c|c|c|c|}
\hline & \multicolumn{5}{|c|}{ RBF } & \multicolumn{5}{|c|}{ MLP } \\
\hline Denemeler & D-9 & D-11 & D-10 & D-5 & D-7 & D-15 & D-21 & D-16 & D-17 & D-19 \\
\hline Test (MAE) & $2.74 \mathrm{gr}$ & $2.63 \mathrm{gr}$ & $2.95 \mathrm{gr}$ & $3.65 \mathrm{gr}$ & $3.43 \mathrm{gr}$ & $3.30 \mathrm{gr}$ & $3.20 \mathrm{gr}$ & $3.05 \mathrm{gr}$ & $3.62 \mathrm{gr}$ & $3.97 \mathrm{gr}$ \\
\hline Test (R) & 0.9760 & 0.9808 & 0.9786 & 0.9621 & 0.9612 & 0.9695 & 0.9581 & 0.9717 & 0.9732 & 0.9581 \\
\hline Doğrulama (MAE) & $2.73 \mathrm{gr}$ & $2.95 \mathrm{gr}$ & $2.47 \mathrm{gr}$ & $3.05 \mathrm{gr}$ & $3.17 \mathrm{gr}$ & $2.69 \mathrm{gr}$ & $3.07 \mathrm{gr}$ & $3.66 \mathrm{gr}$ & $2.66 \mathrm{gr}$ & $3.07 \mathrm{gr}$ \\
\hline Doğrulama (R) & 0.9767 & 0.9782 & 0.9835 & 0.9755 & 0.9710 & 0.9777 & 0.9770 & 0.9590 & 0.9803 & 0.9702 \\
\hline Eğitim (MAE) & $2.28 \mathrm{gr}$ & $2.49 \mathrm{gr}$ & $2.58 \mathrm{gr}$ & $3.01 \mathrm{gr}$ & $3.01 \mathrm{gr}$ & $2.39 \mathrm{gr}$ & $2.42 \mathrm{gr}$ & $2.61 \mathrm{gr}$ & $2.78 \mathrm{gr}$ & $2.33 \mathrm{gr}$ \\
\hline Eğitim (R) & 0.9852 & 0.9818 & 0.9794 & 0.9743 & 0.9747 & 0.9856 & 0.9846 & 0.9826 & 0.9791 & 0.9831 \\
\hline Genel (MAE) & $2.42 \mathrm{gr}$ & $2.58 \mathrm{gr}$ & $2.62 \mathrm{gr}$ & $3.12 \mathrm{gr}$ & $3.10 \mathrm{gr}$ & $2.58 \mathrm{gr}$ & $2.64 \mathrm{gr}$ & $2.84 \mathrm{gr}$ & $2.89 \mathrm{gr}$ & $2.70 \mathrm{gr}$ \\
\hline Genel (R) & 0.9825 & 0.9808 & 0.9808 & 0.9727 & 0.9726 & 0.9820 & 0.9800 & 0.9783 & 0.9775 & 0.9772 \\
\hline
\end{tabular}

Veri kümesi 1; \%50'si eğitim, \%25'i test ve \%25'i doğrulama işlemi için bölünerek oluşturulmuştur. Veri kümesi 2 ise \%34'ü eğitim, \%33'ü test ve \%33'ü doğrulama işlemi için bölünmüştür. Bu veri kümelerinin sırasıyla başarımı en yüksek olan “Deneme 9"a ve "Deneme 15"e uygulanması sonucunda elde edilen başarımlar RBF ve MLP için Tablo 10'da verilmiştir.

RBF modeliyle gerçekleştirilen "Deneme 9"a ve MLP modeliyle gerçekleştirilen "Deneme 15”e KKÇDY, k=5 için uygulanmıştır ve sonuçlar Tablo 11 'de verilmiştir. 
Tablo 10: RBF ve MLP için veri kümelerinin başarımları

\begin{tabular}{c|cc|cc} 
& \multicolumn{2}{|c|}{ RBF } & \multicolumn{2}{c}{ MLP } \\
\hline Başarım & Veri Kümesi 1 & Veri Kümesi 2 & Veri Kümesi 1 & Veri Kümesi 2 \\
\hline Test (MAE) & $2.91 \mathrm{gr}$ & $3.34 \mathrm{gr}$ & $3.63 \mathrm{gr}$ & $3.74 \mathrm{gr}$ \\
\hline Test (R) & 0.9729 & 0.9686 & 0.9621 & 0.9638 \\
\hline Doğrulama (MAE) & $2.91 \mathrm{gr}$ & $3.61 \mathrm{gr}$ & $3.33 \mathrm{gr}$ & $3.27 \mathrm{gr}$ \\
\hline Doğrulama (R) & 0.9769 & 0.9652 & 0.9687 & 0.9710 \\
\hline Eğitim (MAE) & $2.08 \mathrm{gr}$ & $1.85 \mathrm{gr}$ & $2.57 \mathrm{gr}$ & $2.81 \mathrm{gr}$ \\
\hline Ĕgitim (R) & 0.9873 & 0.9907 & 0.9831 & 0.9804 \\
\hline Genel (MAE) & $2.50 \mathrm{gr}$ & $2.93 \mathrm{gr}$ & $3.03 \mathrm{gr}$ & $3.27 \mathrm{gr}$ \\
\hline Genel (R) & 0.9814 & 0.9748 & 0.9744 & 0.9717
\end{tabular}

Tablo 11: RBF ve MLP için KKÇDY başarımı

\begin{tabular}{|c|c|c|c|c|c|c|c|c|c|c|c|c|}
\hline & \multicolumn{6}{|c|}{ RBF } & \multicolumn{6}{|c|}{ MLP } \\
\hline & $\begin{array}{c}\text { Test } \\
\text { (MAE) }\end{array}$ & Test (R) & $\begin{array}{l}\text { Ĕgitim } \\
\text { (MAE) }\end{array}$ & $\begin{array}{l}\text { Ĕgitim } \\
\text { (R) }\end{array}$ & $\begin{array}{c}\text { Genel } \\
\text { (MAE) }\end{array}$ & $\begin{array}{c}\text { Genel } \\
\text { (R) }\end{array}$ & $\begin{array}{c}\text { Test } \\
\text { (MAE) }\end{array}$ & Test (R) & $\begin{array}{l}\text { Eüitim } \\
\text { (MAE) }\end{array}$ & $\begin{array}{l}\text { Ĕgitim } \\
\text { (R) }\end{array}$ & $\begin{array}{c}\text { Genel } \\
\text { (MAE) }\end{array}$ & $\begin{array}{c}\text { Genel } \\
\text { (R) }\end{array}$ \\
\hline $\mathrm{k}=1$ & $2.81 \mathrm{gr}$ & 0.9835 & $2.30 \mathrm{gr}$ & 0,9835 & $2.40 \mathrm{gr}$ & 0,9836 & $3.72 \mathrm{gr}$ & 0.9828 & $1.67 \mathrm{gr}$ & 0.9919 & $2.08 \mathrm{gr}$ & 0.9869 \\
\hline $\mathrm{k}=2$ & $2.82 \mathrm{gr}$ & 0.9659 & $2.35 \mathrm{gr}$ & 0,9855 & $2.44 \mathrm{gr}$ & 0,9823 & $2.92 \mathrm{gr}$ & 0.9680 & $1.36 \mathrm{gr}$ & 0.9950 & $1.67 \mathrm{gr}$ & 0.9905 \\
\hline $\mathrm{k}=3$ & $2.66 \mathrm{gr}$ & 0.9770 & $2.45 \mathrm{gr}$ & 0,9833 & $2.49 \mathrm{gr}$ & 0,9828 & $3.85 \mathrm{gr}$ & 0.9069 & $1.63 \mathrm{gr}$ & 0.9928 & $2.08 \mathrm{gr}$ & 0.9809 \\
\hline $\mathrm{k}=4$ & $3.42 \mathrm{gr}$ & 0.9685 & $2.12 \mathrm{gr}$ & 0,9876 & $2.38 \mathrm{gr}$ & 0,9830 & $3.92 \mathrm{gr}$ & 0.9592 & $1.45 \mathrm{gr}$ & 0.9938 & $1.94 \mathrm{gr}$ & 0.9857 \\
\hline $\mathrm{k}=5$ & $2.18 \mathrm{gr}$ & 0.9901 & $2.38 \mathrm{gr}$ & 0,9828 & $2.34 \mathrm{gr}$ & 0,9839 & $2.96 \mathrm{gr}$ & 0.9846 & $2.72 \mathrm{gr}$ & 0.9836 & $2.77 \mathrm{gr}$ & 0.9825 \\
\hline A.O. & $2.78 \mathrm{gr}$ & 0.9770 & $2.32 \mathrm{gr}$ & 0,9845 & $2.41 \mathrm{gr}$ & $\mathbf{0 , 9 8 3 1}$ & $3.47 \mathrm{gr}$ & 0.9603 & $1.77 \mathrm{gr}$ & 0.9914 & $2.11 \mathrm{gr}$ & 0.9853 \\
\hline
\end{tabular}

\section{Tartışma}

Yumurta örneği için, sistem parametreleri değiştirilerek gerçekleştirilen denemelerden en iyi sonuç veren 5 tanesi karşılaştırıldığında başarımlarının oldukça birbirine yakın olduğu gözlenmiştir. Ayrıca MLP ve RBF modelleri ile yapılan denemelerin sonuçları da birbirine oldukça yakındır. Aradaki küçük farklara rağmen RBF modeli ile gerçekleştirilen "Deneme 3" başarımı en yüksek denemedir. Ayrıca MLP modeli için "Deneme 19" en başarılı sonucu vermiştir. "Deneme 3" için R 0.9943 ve MAE 0.81 gr olarak hesaplanmıştır. Sistemde tespit edilen en büyük mutlak hata ise 3.19 gr olarak hesaplanmıştır. "Deneme 19" için ise R 0.9942 ve ortalama mutlak MAE 0.80 gr olarak hesaplanmıştır. Sistemde tespit edilen en büyük mutlak hata da 2.93 gr olarak hesaplanmıştır.

Yumurtaların sınıflandırma ve denetleme değerleri Türk Gıda Kodeksinin yumurta tebliğine göre yapılmaktadır. Türk Gıda Kodeksine göre 180 'den fazla örnek yumurtanın bulunduğu kontrollerde, alt ağırlık sınıfından karışma oranının \%5'i geçmemesi gerekmektedir. 180 'den az örnek yumurtanın bulunduğu denetlemelerde ise bu değerin \%10'u geçmemesi gerekmektedir. Ayrıca 2 veya daha alt sinıflardan yumurta bulunmamalıdır. Denetlemeler sırasında üst ağırlık sınıfindan karışma durumu ise herhangi bir sorun teşkil etmemektedir (URL-5). Adana'da satışa sunulan yumurtalar üzerinde gerçekleştirilen bir çalışmada, markalara göre değişmekle birlikte paket üzerinde yazan ağılık sınıfına uyma oranının \%95 ile \%60 arasinda değiştiği görülmüştür (Doğan, 2008).

4 farklı markadan elde edilmiş yumurta örneklerinin hassas tartı ile ölçümleri sonucunda alt ağırlık sınıfından karışma oranının \%11 olduğu ve genel doğruluk oranının ise \%47 olduğu tespit edilmiştir. Gerçekleştirilen bu çalışma ile RBF kullanarak alt ağırlık sınıfından karışma oranı \%7.5'e düşürülmüş, genel doğruluk oranı ise \%86.3'e çıkarılmıştır. MLP kullanarak ise alt ağırlık sınıfından karışma oranı \%5'e düşürülmüş, genel doğruluk oranı ise \% 90.5 'e çıkarılmıştır.

RBF modeli ile gerçekleştirilen "Deneme 3"te dik açıyla elde edilmiş; objenin yüzey alanı, objenin çevresi, MEUKN, 
MEYKN ve yuvarlaklık olmak üzere toplam 5 öznitelik vektörü sistemin girişine uygulanmıştır. Yayılma değeri 100, karesel ortalama hata hedefi 1, ekranlar arasına eklenecek nöron sayısı 25 ve maksimum nöron sayısı giriş vektör sayısına eşit olacak şekilde tanımlanmıştır.

MLP modeli ile gerçekleştirilen "Deneme 19"da dik açıyla elde edilmiş; objenin yüzey alanı, objenin çevresi ve yuvarlaklık olmak üzere toplam 3 öznitelik vektörü sistemin girişine uygulanmıştır. Bu denemede tek gizli katman kullanılmış ve gizli katmanda 40 nöron bulunmaktadır. Gizli katman ve çıkış katmanı için aktivasyon fonksiyonu tanjant sigmoid seçilmiştir. Öğrenme fonksiyonu GDX, öğrenme oranı ise 0.5’tir. Öğrenme oranı artış miktarı 1.05, öğrenme oranı azalış miktarı 0.7 olarak ve momentum katsayısı 0.9 olarak belirlenmiştir. Ayrıca iterasyon sayısı 30000 olarak tanımlanmıştır.

Yumurta örneğinde RBF ve MLP modelleri karşılaştırıldığında R değerleri arasında çok büyük farklar olmamasına rağmen Türk Gıda Kodeksine göre sınıflandırma başarımı MLP modeli ile gerçekleştirilen “Deneme 19”da daha yüksek çıkmıştır. Yumurta ağırlıklarının tahmin edilmesindeki esas amaç ticari bir ürün olan yumurtanın doğru sınıflandırılarak müşteriye ulaşması olduğu için burada başarımı en yüksek parametreler belirlenirken öncelikli olarak sınıflandırma başarımı dikkate alınmalıdır. Ayrıca RBF modelinde 5 öznitelik vektörü kullanılırken, MLP modelinde 3 öznitelik vektörü kullanılmıştır. Yani birbirine oldukça yakın olan sistem başarımları MLP modelinde daha az öznitelik vektörüyle elde edilmiştir. Buna ek olarak, KKÇDY yöntemi ile rastlantısallığın azaltıldığı durumda da, farklı veri kümeleriyle eğitim verilerinin azaltıldığı durumlarda da "Deneme 19"un sistem başarımı yüksek çıkmıştır. Bu nedenle yumurta örneği için ağırlık tahmin sisteminde "Deneme 19"un parametrelerinin kullanılması uygun olacaktır.

Portakal örneği için, sistem parametreleri değiştirilerek gerçekleştirilen denemelerden en iyi sonuç veren 5 tanesi karşılaştırıldığında başarımlarının oldukça birbirine yakın olduğu gözlenmiştir. Ayrıca MLP ve RBF modelleri ile yapılan denemelerin sonuçları da birbirine oldukça yakındır. Bu küçük farklara rağmen RBF modeli ile gerçekleştirilen "Deneme 9" başarımı en yüksek denemedir. Ayrıca MLP modeli için "Deneme 15" en başarılı sonucu vermiştir. "Deneme 9” için R 0.9825 ve MAE 2.42 gr olarak hesaplanmıştır. Sistemde tespit edilen en büyük mutlak hata ise 11 gr olarak hesaplanmıştır. “Deneme 15” için ise R 0.9820 ve MAE 2.58 gr olarak hesaplanmıştır. Sistemde tespit edilen en büyük mutlak hata da 10.6 gr olarak hesaplanmıştır.

RBF modeli ile gerçekleştirilen “Deneme 9"da dik, pozitif ve negatif açıyla elde edilmiş; objenin yüzey alanı, objenin çevresi, MEUKN ve MEYKN olmak üzere toplam 12 öznitelik vektörü sistemin girişine uygulanmıştır. Yayılma değeri 10000 , karesel ortalama hata hedefi 1, ekranlar arasına eklenecek nöron sayısı 25 ve maksimum nöron sayısı giriş vektör sayısına eşit olacak şekilde tanımlanmıştır.

MLP modeli ile gerçekleştirilen "Deneme 15"de dik açıyla elde edilmiş; objenin yüzey alanı, objenin çevresi ve yuvarlaklık olmak üzere toplam 3 öznitelik vektörü sistemin girişine uygulanmıştır. Bu denemede tek gizli katman kullanılmış ve gizli katmanda 20 nöron bulunmaktadır. Gizli katman ve çıkış katmanı için aktivasyon fonksiyonu tanjant sigmoid seçilmiştir. Öğrenme fonksiyonu GDA, öğrenme oranı ise 0.5 ’tir. Öğrenme oranı artış miktarı 1.05 ve öğrenme oranı azalış miktarı 0.7 belirlenmiştir. Ayrıca iterasyon sayısı 30000 olarak tanımlanmıştır.

Portakal örneğinde RBF ve MLP model başarımları arasında çok büyük farklar olmamasına rağmen, RBF modeli ile gerçekleştirilen "Deneme 9"un R değeri daha yüksek çıkmıştır. Buna ek olarak, KKÇDY yöntemi ile rastlantısallığın azaltıldı̆̆ 1 durumda da, farklı veri kümeleriyle eğitim verilerinin azaltıldığı durumlarda da RBF modeli için “Deneme 9” un sistem başarımı yüksek çıkmıştır. Bu nedenle portakal örneği için ağırlık tahmin sisteminde “Deneme 9"un parametrelerinin kullanılması uygun olacaktır. 
Yumurta ve portakal örnekleri karşılaştırıldığında yumurtanın ağırlığını tahmin eden en başarılı sistemin girişine 3 öznitelik vektörü uygulanmasına rağmen, portakalın ağırlığını tahmin eden en başarılı sistemin girişine 12 öznitelik vektörü uygulanmıştır. Bu durumun asıl sebebi yumurtanın portakala göre daha simetrik bir yapıya sahip olmasıdır. Bu nedenle ağırlığı ölçülecek objelerin simetrileri bozuldukça farklı açılardan farklı görüntülerin elde edilerek sistemin girişine uygulanması başarımı arttıracaktır.

\section{Sonuçlar}

$\mathrm{Bu}$ çalışmada 250 adet yumurta ve 150 adet portakal örneği ile uzaklıktan bağımsız YSA kullanılarak ağılık tahmin işlemi gerçekleştirilmiştir. Yapılan deneyler sonucunda farklı denemeler için farklı başarımlar elde edilmiştir. Ayrıca, yumurta için dik, pozitif ve negatif açılı olmak üzere 750 adet görüntü, portakal için dik, pozitif ve negatif açılı olmak üzere 450 adet görüntü içeren bir veri tabanı oluşturulmuştur. Gerçekleştirilmiş olan bu çalışmada sabit mesafeden ve sabit bir açıyla ölçüm yapılmamıştır. Literatür taramasında, YSA (MLP veya RBF) kullanarak referans görüntü ile kısmi derecede uzaklıktan ve kamera açısından bağımsız, tek bir kamera ile 3 farklı açıdan elde edilen görüntüleri birleştirerek ağırlık tahmini yapan bir sisteme rastlanılmamıştır. Ayrıca bu özgün yöntemde, yumurta örneğinde sınıflandırma Türk Gıda Kodeksine göre yapılmıştır. Dolayısıyla çalışma daha özgün hale gelmiştir. Buna ek olarak bu çalışmada kullanılan veri kümesine benzer bir veri tabanına da rastlanılmamışıı. Oluşturulan veri kümesinin araştırmacılarla paylaşılacak olması, ileri de yapılacak çalışmaların temelini oluşturacak ve araştırmacılara hatırı sayılır bir zaman kazandıracaktır.

$\mathrm{Bu}$ çalışma sonucunda; Türk Gıda Kodeksi Yumurta Tebliği baz alınarak hassas tartı ile gerçekleştirilen ölçüm sonuçlarına göre ortaya çıkan doğruluk oranı \%47'den MLP'de \%90.5'e, RBF'de \%86.3'e çıkarılmıştır. Ayrıca, yumurta örneği için RBF'de \%99.43, MLP'de \%99.42, portakal örneği için RBF'de \%98.25, MLP'de \%98.20 ağırlık tahmin başarımı elde edilmiştir.

$\mathrm{Bu}$ çalışmanın geliştirilmesi amacıyla da bazı öneriler getirilmiştir. Yapılan bu çalışmada tek bir kamera kullanılarak farklı açılardan görüntüler elde edilmiştir. İleride gerçekleştirilecek çalışmalarda iki veya daha fazla kamera ile görüntüler eş zamanlı olarak elde edilerek ağırlık tahmini yapılabilir. Bu çalışmada, bir objenin ağırlığının hızlı olarak tahmin edilmesinden ziyade doğru olarak tahmin edilmesi üzerine çalışmalar gerçekleştirilmiştir. Bu nedenle bir obje başına düşen ağırlık tahmin süresi ve bu sürenin iyileştirilmesi konuları üzerinde çalışmalar yapılabilir. Örneğin bu çalışmada aynı anda sadece bir objenin ağırlığı tahmin edilmekte iken aynı anda birden fazla objenin ağırlığının tahmin edilebileceği bir sistem düzeneği kurularak obje başına düşen ağırlık tahmin süresi azaltılabilir. Ayrıca sonraki çalışmalarda yumurta ve portakaldan farklı objeler kullanarak sistemin başarımı tekrar ölçülebilir. Özellikle kullanılan objelerin sebze, meyve, yumurta vb. şekilde gıda ürünü olması durumunda son kullanma tarihlerinin ve tazelik durumlarının göz önünde bulundurularak sistemin eğitilmesi ve bu veriler doğrultusunda ağırlık tahmini yapılması da sağlanabilir.

\section{Bilgilendirme}

$\mathrm{Bu}$ çalışmada kullanılan veri tabanı araştırmacılara açık haldedir. Yazarlara e-posta atılması durumunda bu veri tabanı ücretsiz olarak araştırmacılar ile paylaşılacaktır.

\section{Kaynaklar}

Alikhanov, D., Penchev, S., Georgieva, T., Moldajanov, A., Shynybaj, Z., \& Daskalov, P. (2015). Indirect Method for Egg Weight 
Measurement Using Image Processing. International Journal of Emerging Technology and Advanced Engineering, 5, 30-34.

Asadi, V., \& Raoufat, M. H. (2010). Egg weight estimation by machine vision and neural network techniques (a case study fresh egg). International Journal of Engineering, Technology and Natural Sciences, (2), 1-4.

Aydar U. (2007). Cephe değerlendirmelerinde fotogrametrik ve görselleştirme yöntemlerinin klyaslanması (Yüksek Lisans Tezi). İstanbul Teknik Üniversitesi Fen Bilimleri Enstitüsü, İstanbul, Türkiye.

Çelebi, Ş., \& Karaca, H. (2006). Yumurtanın besin değeri, kolesterol içeriği ve yumurtayı n-3 yağ asitleri bakımından zenginleştirmeye yönelik çalışmalar. Atatürk Üniversitesi Ziraat Fakültesi Dergisi, 37(2), 257-265.

Çelik, Y., \& Şengül, T. (2001). Şanlıurfa ili kentsel alanında tüketicilerin yumurta tüketim düzeyleri ve tüketim alışkanlıklarının belirlenmesi. Hayvansal Üretim, 42(2).

Çiçekgil, Z. (2014). Kümes hayvancılığı ürün raporu, https://arastirma.tarim.gov.tr/tepge/Lists/Haber/Attachments/18/KANATLI_URUN _RAPORU_2014.pdf(Erişim Tarihi: 10.02.2018).

Çölkesen, İ. (2009). Uzaktan algılamada ileri sınıflandırma tekniklerinin karşılaştırılması ve analizi (Yüsek Lisans Tezi). Gebze Yüksek Teknoloji Enstitüsü Mühendislik ve Fen Bilimleri Enstitüsü, Kocaeli, Türkiye.

Doğan, H., (2008). Adana 'da satışa sunulan yumurtalarda sunuş çeşitliliği ve kalite değişimi üzerine bir çalışma (Yüsek Lisans Tezi). Çukurova Üniversitesi Fen Bilimleri Enstitüsü, Adana, Türkiye.

Gonzalez, A., Satterlee, D. G., Moharer, F., \& Cadd, G. G. (1999). Factors affecting ostrich egg hatchability. Poultry science, 78(9), 12571262.

Hartley, R., \& Zisserman, A. (2003). Multiple view geometry in computer vision. Cambridge university press.

Haykin, S. (1994). Neural networks: a comprehensive foundation. Prentice Hall PTR.

Heikkila, J., \& Silven, O. (1997, June). A four-step camera calibration procedure with implicit image correction. In cvpr (Vol. 97, p. 1106).

Hockaday, S., Ross, L. G., \& Tillett, R. D. (1997). Using stereo image pairs to measure mass in strains of Atlantic salmon, Salmo salar L. Sensors and Their Applications VIII, Section A Environmental and Biomedical Sensors, 7, 21-26.

James, G., Witten, D., Hastie, T., \& Tibshirani, R. (2013). An introduction to statistical learning (Vol. 112, p. 18). New York: springer.

Javadikia, P., Dehrouyeh, M. H., Naderloo, L., Rabbani, H., \& Lorestani, A. N. (2011, December). Measuring the weight of egg with image processing and ANFIS model. In International Conference on Swarm, Evolutionary, and Memetic Computing (pp. 407-416). Springer, Berlin, Heidelberg.

Kashiha, M., Bahr, C., Ott, S., Moons, C. P., Niewold, T. A., Ödberg, F. O., \& Berckmans, D. (2014, October). Weight Estimation of Pigs Using Top-View Image Processing. In International Conference Image Analysis and Recognition (pp. 496-503). Springer, Cham.

Kraus, K. (2007). Fotogrametri. Cilt 1, Nobel Yayın Dağıtım.

Kriesel, D., (2005). A brief introduction to neural networks, http://www.dkriesel.com/en/science/neural_networks (Erişim Tarihi:4 Kasım 2017).

Kohavi, R. (1995, August). A study of cross-validation and bootstrap for accuracy estimation and model selection. In Ijcai(Vol. 14, No. 2, pp. 1137-1145).

Lines, J. A., Tillett, R. D., Ross, L. G., Chan, D., Hockaday, S., \& McFarlane, N. J. B. (2001). An automatic image-based system for estimating the mass of free-swimming fish. Computers and Electronics in Agriculture, 31(2), 151-168.

Omid, M., Khojastehnazhand, M., \& Tabatabaeefar, A. (2010). Estimating volume and mass of citrus fruits by image processing technique. Journal of food Engineering, 100(2), 315-321.

Şalvarcı, Ü.B., Ayten, U.E., (2017). Yapay sinir ağları kullanılarak imgelerden yumurta ağırlığının uzaklıktan bağımsız sezimi. SIU, 1-4, Antalya.

Şalvarcı, Ü.B. (2017). Yapay sinir ağları kullanarak görüntü işlemeye dayalı ağırlık tahmini (Yüksek Lisans Tezi). Y1ldız Teknik Üniversitesi Fen Bilimleri Enstitüsü, İstanbul, Türkiye.

Wilson, H. R. (1991). Interrelationships of egg size, chick size, posthatching growth and hatchability. World's Poultry Science Journal, 47(1), 5-20.

URL-1: Withings, (2011). A short history of the weighing scale. https://blog.withings.com/2011/09/30/a-short-history-of-the-weighingscale-2/ (Erişim Tarihi: 30.03.2019).

URL-2: Psikolojik, yapay sinir ağları, http://www.psikolojik.gen.tr/yapay-sinir-aglari.html, (Erişim Tarihi: 7 Kasım 2017).

URL-3: Safari book online, Multi layer perceptron, https://www.safaribooksonline.com/library/view/getting-started-with/ 
9781786468574/ch04s04.html, (Erişim Tarihi: 10 Kasım 2017).

URL-4: DTREG, RBF neural networks, https://www.dtreg.com/solution/view/25, (Erişim Tarihi: 8 Kasım 2017).

URL-5: Gıda Tarım ve Hayvancılık Bakanlığı, (2014), Türk Gıda Kodeksi Yumurta Tebliği http://www.resmigazete.gov.tr/eskiler/2014/ 12/20141220-5.htm (Erişim Tarihi: 19 Mart 2018). 